Capítulo 2

\title{
ESTUDIOS SOBRE LOS MOVIMIENTOS SOCIALES. ENTRE EL NEOLIBERALISMO Y POS-NEOLIBERALISMO
}

\author{
José Luis Bonifacio, Juan Wahren y Andrea Villagrán
}

\section{Introducción}

Desde una perspectiva de mediano plazo, los movimientos sociales en la Argentina han sido estudiados en las ciencias sociales teniendo como telón de fondo la impronta de la última dictadura cívico-militar (1976-1983) y la apertura democrática en 1983. En aquellos estudios se tematizó centralmente al movimiento por los Derechos Humanos, y en menor medida a los movimientos de jóvenes y su vinculación con el rock nacional, de mujeres, movimientos barriales en áreas urbanas populares (Jelin, 1985). Estos movimientos fueron considerados centrales en la resistencia a la dictadura y la conquista de la democracia.

Sin embargo, luego de la crisis hiperinflacionaria de 1989 junto al proceso que sobrevino en la década de 1990, comenzaron a manifestarse nuevos actores que anunciaban movimientos sociales de nuevo tipo. Estos movimientos germinaron por el cambio del contexto económico, político y social. No representaban una ruptura con las luchas del período anterior, sino que irrumpían en la esfera pública como consecuencia de un proceso que en la Argentina algunos autores definieron como modernización excluyente (Barbeito y Lo Vuolo, 1995). El punto culminante de esta etapa se produjo durante la crisis de diciembre del año 2001, que representó y se convirtió en un momento histórico fundacional, ya que la movilización social generalizada terminó por consolidarse como un rasgo de construcción identitaria de los movimientos sociales que habían surgido bajo el signo del neoliberalismo.

Prontamente las ciencias sociales emprendieron el estudio de estos "nuevos movimientos sociales"; la mayor parte de las veces bajo renovados supuestos teórico-metodológicos y sometiendo a la crítica los anteriores paradigmas. Se trataba de entender la nueva dinámica a partir de la elabora- 
ción de categorías teóricas que captasen las profundas transformaciones que había sufrido la sociedad argentina y los cambios en las formas de acción colectiva. Un número importante de investigaciones asumió nuevas teorizaciones sobre los movimientos sociales utilizando modelos de análisis que recuperaron de la tradición de estudios que desarrollaron pensadores europeos y norteamericanos, cuyos representantes más conspicuos fueron Tilly (1986), Tarrow (2004), McAdam, McCarthy y Zald (1999), quienes habían logrado una síntesis teórica luego de largas disputas. El uso de este soporte teórico importado no se realizó sin críticas, ya que desde mediados de la década de 1990 la situación latinoamericana comenzó a mostrar una productividad política tan novedosa que interpeló a las y los intelectuales especialmente para discutir los modelos de desarrollo que se habían comenzado a poner en práctica. En este escenario muchos investigadores se propusieron revisar a teóricos que hacía décadas habían tematizado esta región con sus especificidades históricas y cuestionaban la colonialidad del saber: René Zavaleta Mercado, Aníbal Quijano, Baovantura de Souza Santos, entre otros.

En este capítulo nos ocuparemos de presentar los resultados de los estudios que abordaron la movilización colectiva de actores sociales en el período 2000-2012, tales como: trabajadores desocupados y de fábricas recuperadas, asambleístas ambientales, agricultores familiares, campesinos, pueblos originarios, organizados en torno a la búsqueda de trabajo, provocados por la crisis de la sociedad salarial y la lucha y disputa por el territorio frente al Estado y sectores del capital.

Los estudios analizados abordan temas que se desarrollaron durante el auge y la crisis del neoliberalismo, momento en el cual es posible identificar diversas respuestas que surgieron dentro de la sociedad civil en la forma de procesos de movilización, protesta y organización de múltiples actores sociales que desplegaron un renovado repertorio de acciones colectivas. A manera de síntesis mencionamos algunas de las respuestas colectivas que durante el período de análisis 2000-2012 fueron las que mayor atención recibieron de los investigadores en ciencias sociales según la base de datos que elaboramos en el PISAC:

- Entre las puebladas de mediados de la década de 1990 protagonizadas en ciudades de algunas provincias, las más emblemáticas fueron: Santiago del Estero en 1993, Cutral Co y Plaza Huincul en Neuquén en 1996 y 1997, Mosconi y Tartagal en Salta a partir de 1997. 
- De las experiencias de Neuquén y Salta, que se extienden rápidamente al conjunto del país, especialmente al conurbano bonaerense, nacen los movimientos piqueteros. Este fenómeno social y político, enmarcado en los crecientes índices de desocupación de mediados de los años noventa, generó específicas formas de protesta, modalidades de organización y acción colectiva. Estos nuevos formatos de protesta y organización fueron recreados a partir de matrices comunitarias y sindicales aprendidas a lo largo de sus trayectorias y experiencias colectivas de lucha.

- Las asambleas barriales, surgidas al calor de la crisis de diciembre de 2001, generalmente en barrios de clase media, cuya movilización y compromiso no respondió solo a una necesidad económica de los propios asambleístas (no solo se trató de ahorristas) sino básicamente a la crisis político-institucional de representación.

- Las empresas recuperadas por sus trabajadores después de su quiebra, cierre o abandono por parte de sus anteriores propietarios. Un proceso que se inicia a fines de los años noventa, pero que asume particular intensidad a partir del año 2002.

Promediando la nueva década del siglo xxI, al momento de un impasse en la situación social de los movimientos sociales antes mencionados, comenzaron a gestarse nuevas formas de protesta, esta vez planteadas por sectores sociales que sufrían las consecuencias del modelo de desarrollo neoextractivista ${ }^{1}$ que se había puesto en marcha unas décadas atrás, pero que comenzaban a generar severas dificultades o preocupaciones futuras para la cotidianidad de algunas comunidades. Emergieron entonces los autodeno-

El concepto de neoextractivismo comenzó a ser utilizado en la literatura crítica latinoamericana entre otros por Gudynas (2009), Zibechi (2011) y Massuh (2012) para caracterizar la inserción de América Latina en un nuevo orden económico, político-ideológico sostenido por el boom de los precios internacionales de las materias primas y los bienes de consumo demandados cada vez más por los países centrales y las potencias emergentes. Svampa (2013: 34) define desarrollo neoextractivista "como aquel patrón de acumulación basado en la sobreexplotación de recursos naturales, en gran parte no renovables, así como en la expansión de las fronteras hacia territorios antes considerados como 'improductivos'. El neoextractivismo instala una dinámica vertical que irrumpe en los territorios y a su paso va desestructurando economías regionales, destruyendo biodiversidad y profundizando de modo peligroso el proceso de acaparamiento de tierras, al expulsar o desplazar a comunidades rurales, campesinas o indígenas, y violentando procesos de decisión ciudadana”. 
minados movimientos socio-ambientales. ${ }^{2}$ Estos movimientos resignificaban demandas como las luchas por la tierra, el agua o formas de vida locales y fueron emprendidos por nuevos actores sociales como asambleas de vecinos autoconvocados que en algunos casos articularon con viejos actores, pueblos indígenas, comunidades campesinas, en pos de objetivos comunes: la defensa del territorio frente a diversos proyectos extractivos que generan altos impactos socio-ambientales.

No fueron las únicas manifestaciones de protesta, movilización y organización de movimientos sociales que se registraron, también es dable destacar otros procesos colectivos como las mujeres agrarias en lucha en la década de 1990 (Giarraca y Teubal, 2001); los procesos ligados a la economía social como las redes de trueque de finales de esa década y que alcanzaron una amplia extensión en el año 2002 (González Bombal, 2002); el movimiento estudiantil que asumió un nuevo ímpetu, en su larga trayectoria de luchas, a inicios de la década de 2000, contra la Ley de Educación Superior (Liaudat, Liaudat y Pis Diez, 2012); las organizaciones de ahorristas (Gómez, 2014), los colectivos culturales y de contrainformación (Vinelli y Rodríguez Esperón, 2004), que fueron conformando espacios colectivos de nuevas subjetividades políticas.

Para componer este capítulo se consideró una selección, en una primera instancia, de 206 trabajos (libros, capítulos de libros, artículos de revistas y ponencias) buscando intencionalmente que estén representadas todas las regiones del país y los casos menos visibles en el campo de estudio. Esta selección nos permitió identificar la importancia otorgada a determinados temas en el período analizado y establecer los criterios generales de demarcación para la organización de este capítulo. Sobre la muestra de los 206 textos posteriormente se seleccionaron intencionalmente 40 estudios que nos permitieron dar cuenta en profundidad de las concepciones generales sobre el tema abordado, las dimensiones de análisis y su vinculación, las orientaciones teóricas y metodológicas, así como de la bibliografía asumidas por los autores. Además, en estos 40 trabajos ponderamos los resultados y la rele-

2 También son denominados "Movimientos socio-territoriales", que es un modo más amplio de designarlos. Esta caracterización es utilizada entre otros, por B. Mançano F, y otros destacados geógrafos brasileños Milton Santos, Carlos Porto Gonçalves; Giarracca y varios de los autores aquí citados en Argentina; T. Palau en Paraguay; Raúl Zibecchi en Uruguay 
vancia de la investigación en el marco del conjunto de los trabajos presentados sobre los temas en cuestión. La pretensión de este proceso metodológico tuvo la intención de construir un estado de la cuestión que dé cuenta de los temas de investigación, las orientaciones teóricas y los enfoques metodológicos prevalecientes, así como la distribución institucional y espacial de la producción científico social sobre los temas aquí analizados.

Sobre la base de estas consideraciones organizamos este capítulo en las siguientes secciones. En primer lugar abordamos de manera específica la crisis del ańo 2001. Este apartado se justifica por varias razones. Si bien se relevaron escritos anteriores a la crisis del año en cuestión (aproximadamente $10 \%$ ), la gran mayoría de los autores enmarca sus investigaciones en este hecho. Para un importante número de investigadores representó un punto de inflexión, en tanto desencadenó nuevos temas y produjo interrogantes que ya estaban instalados en las ciencias sociales argentinas, pero que en el marco de la crisis asumieron renovados significados. Además, considerando el público destinatario de este trabajo -pretendemos que sea en su mayoría jóvenes estudiantes universitarios de grado de las áreas de ciencias sociales y humanas- creímos necesario desarrollar algunos contenidos históricos y analíticos tal como fueron presentados por los autores relevados. En segundo lugar, se presentan los temas que trataron las investigaciones relevadas en nuestra base de datos y el período en que se realizaron. Algunos de los debates que se presentaron, los grupos e intelectuales que estudiaron la conflictividad social y algunos de los aportes teóricos y metodológicos que pasaron a formar parte de las ciencias sociales en la Argentina. Posteriormente presentamos las investigaciones que analizaron las respuestas de la clase trabajadora a la ofensiva neoliberal expresadas en dos grandes movimientos. A saber: los movimientos piqueteros y el movimiento de fábricas recuperadas por sus trabajadores. Luego, se presentan los estudios sobre los movimientos socio-ambientales especialmente las luchas sociales emprendidas en torno a las consecuencias del agronegocio, la megaminería, la construcción de represas y pasteras y conflictos ambientales urbanos. Finalmente, presentamos las investigaciones que se dedican a los pueblos originarios y su histórica lucha por el territorio. 


\section{Los Estudios sobre la crisis del año 2001}

El 20 de diciembre del año 2001 el presidente Fernando de la Rúa, que había ganado las elecciones dos años antes, debió renunciar a su cargo como consecuencia de una gran rebelión popular. En aquel momento histórico una ciudadanía movilizada demandó una transformación profunda de la política al grito de la consigna "Que se vayan todos".

Para una parte importante de los investigadores en ciencias sociales, la crisis de diciembre de 2001 representa un punto de inflexión a partir del cual era posible volver a analizar e interpretar la historia reciente. En la Argentina la vuelta de la democracia en 1983 había constituido la clave interpretativa para comprender el devenir de la sociedad; ahora la crisis del 2001, con su despliegue de movilización colectiva ofrecía una nueva clave interpretativa para entender la tragedia de una sociedad desgarrada sumida en el desempleo, la pobreza y la desigualdad.

La producción científica en ciencias sociales, en muchos casos definida a sí misma como militante, no se hizo esperar. Uno de los primeros textos escrito al calor de los acontecimientos del 19 y 20 de diciembre de 2001 sintetizaba las condiciones económicas, sociales y políticas en las cuales se enmarcaba la movilización que pasó a ser nominada como el "Argentinazo”. El texto de Fradkin (2002) tenía como puntos salientes:

En diciembre de 2001 la Argentina acumulaba 42 de meses de recesión económica sin perspectiva de recuperación. El endeudamiento externo, que había funcionado como el principal mecanismo de financiamiento durante la década de 1990, prácticamente estaba cerrado para el gobierno argentino. En el mes de junio el ministro de Economía Domingo Cavallo lanzó el programa de "Déficit Cero"3 que acentuó la recesión, la caída de la recaudación y el déficit fiscal. Esta política, destinada a continuar pagando los intereses de la deuda externa, intensificó la fuga de reservas y los depósitos del sistema bancario, que en ocho meses cayeron más de un $25 \%$. Para salvar del colapso al sector financiero, el 3 de di-

3 La ley de Déficit Cero representaba un recorte general de gastos en la administración pública para evitar gastar más de lo que ingresaba en el Estado; el ajuste incluyó una baja de salarios públicos y pensiones del 13\%. 
ciembre el gobierno bloquea los depósitos y salarios convirtiéndolos en el seguro de preservación de este sistema.

"La conjunción no podía ser más explosiva: la economía informal, aquella que da de vivir a no menos del 50\% de la población, recibía un golpe de muerte; la gigantesca aspiradora puesta sobre el circulante convirtió a esas monedas que la mendicidad, la venta ambulante o el arrebato antes proveían en un objeto precioso, el límite ante el abismo del hambre. Por su parte, los sectores medios veían congelada su capacidad de consumo y las ilusiones forjadas en torno al dólar barato; el Estado nacional y los provinciales interrumpían los servicios esenciales (comedores escolares, asistencia social, colapso del sistema de salud pública) y más aún el pago de salarios se postergaba sine die."

"El INDEC anunció a mediados de diciembre los resultados de sus encuestas: la tasa de desocupación llegaba en octubre al 18,3\% (unas 2.532 .000 de personas) y la de subocupación al $16,4 \%$, es decir que al menos un $34,7 \%$ de la PEA estaba con serios problemas de empleo." [...] "En un país de 36 millones de habitantes -según los datos del último censo que a duras penas el gobierno pudo realizar por la resistencia del gremio docente- más de 14 millones se ubican por debajo de la línea de pobreza en los aglomerados urbanos y 16 millones si se considera también la población rural" [...] "la década del 90 fue al mismo tiempo la que presenció la llamada 'Segunda Revolución de las Pampas' -que duplicó la producción agrícola y triplicó las exportaciones de este origen- mientras diseminó la pobreza a niveles nunca antes vistos.”

A la crisis económica y social se sumó la crisis política. Desde el 5 de octubre de 2000, tras la renuncia del vicepresidente Carlos “Chacho" Álvarez, el resquebrajamiento de la Alianza era evidente y adoptó forma definitiva en marzo con el nombramiento de Cavallo en el Ministerio de Economía: su demostración más estridente fue el colapso electoral del 14 de octubre de 2001, cuando la Alianza perdió 5 millones de votos respecto de dos años atrás. [...] El dato central e ineludible de estas elecciones fue el brutal crecimiento de la abstención electoral y, sobre todo, del voto en blanco y del voto impugnado: sumados llegaron a ser el 40\% del padrón electoral.

Todas estas contradicciones, sumadas a las que se vinieron acumulando durante la década menemista, estallaron durante diciembre de 2001 y alcanzaron su punto más álgido el 19 y el 20 de diciembre, cuando las 
clases subalternas salieron a las calles y desplegaron todo el repertorio de acciones colectivas que habían aprendido a utilizar como mecanismo defensivo ante el ajuste neoliberal practicado durante la década de 1990.

La gran movilización popular que se desplegó en diciembre de 2001 es analizada desde varias perspectivas por los autores relevados. Considerando que no había sido convocada por ninguna organización, ni partido político, ni medio de comunicación, emergió el interrogante sobre la espontaneidad de la movilización. La respuesta fue casi unánime, estábamos ante un acontecimiento que era parte de un ciclo de protesta más amplio.

"Si bien inéditos por su magnitud y sus consecuencias, los episodios de diciembre de 2001 [...] deben ser enmarcados en los cambios que la acción colectiva ha sufrido en los últimos tiempos en la Argentina. Lejos de ser una 'explosión' de una ciudadanía que hasta entonces parecía 'ensimismada, incapaz de expresar su descontento', diciembre representa el punto álgido de un proceso de movilización popular que lleva casi una década" (Auyero, 2002: 11).

"El ciclo se desarrolla desde formas espontáneas a formas sistemáticas de lucha, y se va conformando una fuerza social, cualquiera sea su grado de constitución, desde las estructuras económico-sociales caracterizadas por la presencia de población agrícola, de superpoblación inserta en el empleo estatal o de capitalismo en enclaves, hacia el centro del capitalismo argentino" (Iñigo Carrera y Cotarelo, 2003).

Para entender por qué el ciclo de protesta había culminado de manera tan estrepitosa, los investigadores reconstruyeron diversos procesos sociales e incluso llevaron a cabo una crítica acerca de por qué causó tanta conmoción entre los científicos sociales. ${ }^{4}$ Veamos cómo los investigadores reconstruyeron el proceso social que se fue gestando para terminar en la crisis de 2001, lo cual les llevó a prestar atención a la trama organizativa generada una década antes y al despliegue de un renovado o resignificado repertorio de acciones colectivas.

Ińigo Carrera y Cotarelo especificaban que tanto el desarrollo de las formas de lucha como el proceso de formación de fuerza social indican

4 El debate intelectual acerca de por qué la crisis del año 2001 tomó por sorpresa a las ciencias sociales es tematizado en el capítulo introductorio y en el capítulo sobre Ciudadanía. 
que la insurrección de diciembre se encuentra dentro del ciclo de enfrentamientos sociales. "El proceso tiene sus hitos en el motín de Santiago del Estero (1993), la lucha callejera en varias capitales provinciales (1995), la toma y defensa de una posición con barricadas en Cutral Có-Plaza Huincul (1996 y 1997), Jujuy y General Mosconi (1997), Corrientes (1999), Tartagal-General Mosconi (2000 y 2001), GBA (2001). En ese proceso las huelgas generales, jornadas y marchas de protesta (como la Marcha Federal en 1994), y las Jornadas Piqueteras en 2001, constituyen momentos de articulación nacional.” Todo este proceso que recorre desde el motín hasta la insurrección y de lo local a lo nacional, culmina con el estallido de la crisis económica, una de cuyas manifestaciones fue la desaparición del dinero, todas las fracciones y capas sociales se movilizan en forma simultánea y en todo el territorio nacional (Ińigo Carrera y Cotarele, 2003).

Zibechi (2003) señalaba en su Genealogía de la revuelta que los procesos organizativos y las formas de la protesta de la Argentina durante la década de 1990 fueron gestando un entramado organizativo previo que explica la explosión de la rebelión del 19 y 20 de diciembre de 2001. Da cuenta de nuevos formatos organizativos, así como nuevas formas de la protesta social a través de reconstruir distintas experiencias de movimientos sociales: movimiento piquetero, movimiento estudiantil, movimiento barrial, de derechos humanos (Madres de Plaza de Mayo e H.I.J.O.S.), sindicales (CTA) y otras expresiones juveniles. Propone que este período de la Argentina implica la construcción de nuevas formas de hacer política, diferentes de las de la izquierda tradicional, ampliándose así los horizontes de las luchas por la emancipación social. Así concluía que: "la agitación comenzó en el interior y los saqueos fueron su aspecto más visible. Pero hubo de todo: manifestaciones, cortes de rutas y calles, ataques a sedes del gobierno federal y a los municipios, reclamos ante las autoridades, incendios, barricadas, cacerolazos, ollas populares y todas las formas de protesta que venían practicando los argentinos, las nuevas y las viejas, ensayadas en miles de acciones a lo largo de una década".

Estas reconstrucciones históricas, sin bien tienen puntos de convergencia, dejen entrever uno de los debates generados en torno a estas jornadas, a saber: ¿quiénes fueron los principales protagonistas? Para Iñigo Carrera y Cotarelo "el principal protagonista de la rebelión fueron los tra- 
bajadores asalariados: la mayor parte de las acciones de protesta fueron realizadas por asalariados ocupados. Incluso los cortes de calles y rutas, atribuidos generalmente a los trabajadores desocupados, fueron utilizados principalmente por asalariados ocupados y pequeños propietarios".

Sin embargo, para un gran número de intelectuales la crisis daba lugar al protagonismo de los movimientos sociales e interpretaban que la rebelión popular del 19 y el 20 de diciembre de 2001, sin dejar de ser parcialmente un emergente de los procesos previos de recomposición de las clases subalternas, era básicamente el punto de partida o acontecimiento instituyente, de un nuevo ímpetu a los movimientos sociales gestados y en gestación en la resistencia al neoliberalismo. ${ }^{5}$

Finalmente, uno de los tantos debates que surgieron de aquellas jornadas y que aún no ha sido saldado trata acerca del significado político cultural de las jornadas de diciembre de 2001 y el proceso de normalización que comenzó a gestarse a partir del año 2003-2004 con la asunción del Néstor Kirchner en la presidencia de la nación. El debate trata de establecer sí el ciclo abierto de luchas sociales en el año 2001 está cerrado. En esta discusión participan una parte de los autores citados y de manera tácita o explícita vuelve a surgir de manera recurrente.

Este tipo de enfoque, sobre los hechos de diciembre de 2001, que arribaban a resultados semejantes (el estallido no fue espontáneo y representa parte de un ciclo de lucha más amplio; se desarrolló desde luchas locales en las provincias que posibilitaron un entramado organizativo previo, con sus hitos épicos pero también en la cotidianidad de la lucha; la crisis se expandió desde las provincias al centro político del país), se sustentaban en bases teóricas divergentes que en el marco de la crisis entraron en un intenso debate que se prolongó en las formas en que las y los investigadores definieron sus objetos de estudio y los modos de abordarlo.

5 Hay también una lectura de los hechos menos difundida; desde una mirada periodística (Bonasso, 2006) y desde una perspectiva que analiza la dinámica política de la violencia colectiva, a través de la construcción del concepto de "zona gris" (Auyero, 2007); se establecen relaciones "clandestinas" en torno a la organización de los saqueos entre miembros del Partido Justicialista, líderes populares y fuerzas de seguridad. 


\section{Temas y perspectivas teórico-metodológicas y debates en tiempos de crisis}

La crisis del año 2001 fue el punto de referencia del período analizado; por considerar el acontecimiento como punto de inflexión de una nueva etapa o como un hito más de las luchas sociales en la Argentina. En cualquiera de los casos los intelectuales se vieron inmersos en un tiempo histórico crítico que los interpelaba.

Considerando este hecho, nos fue posible identificar dos momentos en los estudios sobre los movimientos sociales en el período 2000-2012. El primero podríamos decir que va desde la crisis del ańo 2000 hasta el año 2006, en donde predominan el estudio de los movimientos sociales relacionados con las crisis de la sociedad salarial, el resto del período 20072012 identificamos el creciente interés por los estudios de los movimientos relacionados con los conflictos socio-ambientales y territoriales (Ver gráfico $\mathrm{N}^{\circ} 1$ ). En todo el período, a pesar del cambio en el objeto persistió la referencia a enmarcarlos en la crisis del modelo neoliberal, que había hecho eclosión en la Argentina en el año 2001.

\section{Gráfico 1. Cantidad de trabajadores elaborados por tema y año}

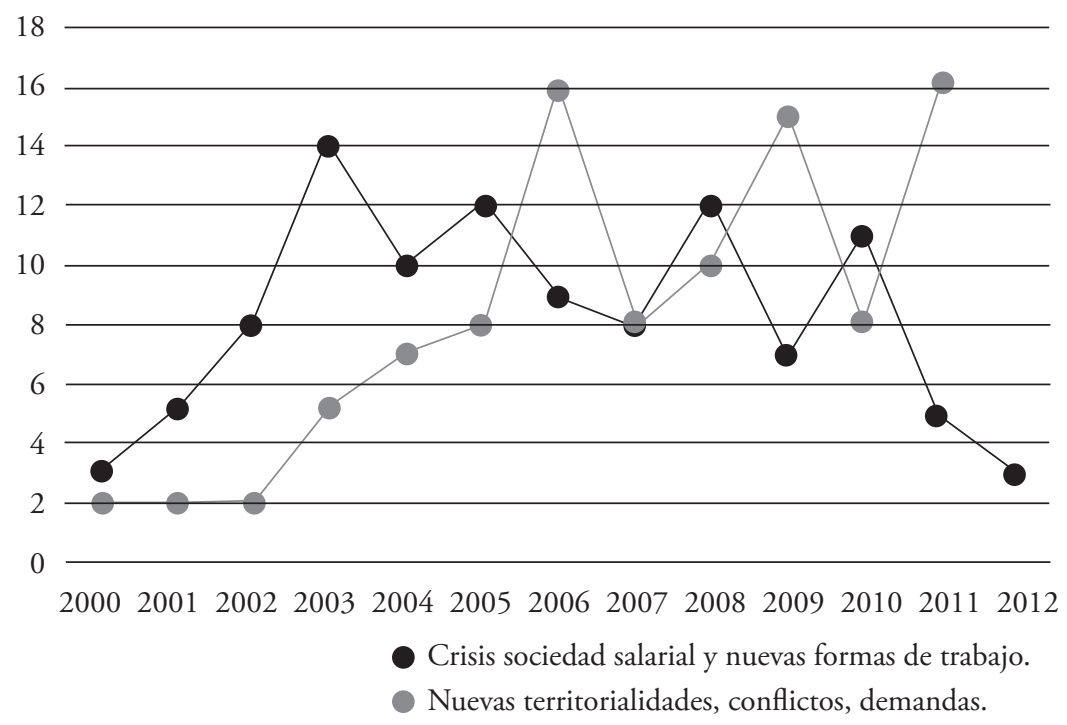

Fuente: Base de datos PISAC. 
Durante los primeros años del período 2001-2006, los temas centrales fueron: cómo interpretar lo sucedido en las jornadas de diciembre de 2001, los movimientos piqueteros, el movimiento de fábricas recuperadas. Un núcleo de científicos sociales e intelectuales de izquierda interpretó los hechos con las herramientas clásicas del marxismo, a saber: Ińigo Carrera y Cotarelo (2003), Altamira (2002), pero un heterogéneo grupo sin abandonar de manera definitiva las bases teóricas del marxismo cuestionó núcleos importantes de la teoría política marxista e introdujo en el análisis debates sobre la autonomía, el contrapoder, anti-poder, el poder popular, que incluso arraigaron en la praxis política de algunos movimientos sociales.

Dos publicaciones provocaron intensos debates intelectuales; Cambiar el mundo sin tomar el poder (2002) de John Holloway e Imperio (2002) de Michael Hardt y Antonio Negri. Estas expresiones intelectuales tuvieron sus seguidores locales, incluso produciendo investigaciones empíricas, este el caso de Zibechi (2003), el Colectivo Situaciones (2001 y 2002). Sin embargo, esta corriente recibió duras críticas de un amplio y heterogéneo grupo de intelectuales, los cuales de manera más confrontativa (Borón, 2002) o en tono de diálogo (Thwaites Rey, 2004), cuestionaron las perspectivas teóricas autonomistas.

Hay que destacar, que antes de que surgieran estos encendidos debates incitados por la crisis abierta en diciembre de 2001, la conflictividad social en la Argentina era una preocupación central de investigadores. El Programa de Investigación sobre el movimiento de la Sociedad Argentina (PIMSA), dirigido por Nicolás Iñigo Carrera desde el año 1993 y aún en vigencia, es llevado adelante por un conjunto de investigadores formados en distintas disciplinas, articulados en equipos de investigación que pretenden integrar distintas aproximaciones al conocimiento de la realidad social. En el sitio oficial de Internet del PIMSA están disponibles de manera abierta una importante cantidad de documentos y comunicaciones relacionadas con el tema de este núcleo temático del PISAC. A modo de ejemplo citamos los documentos relacionados con la "Cronología del conflicto social en la Argentina: actualizado a noviembre de 2014", ${ }^{6}$ que constituye una importante fuente para aportar a investigaciones sociales. 
Otro grupo de intelectuales, desde la Universidad General Sarmiento, a finales de la década de 1990 escribió un libro sugestivamente titulado Desde abajo. La transformación de las identidades sociales, en el cual realizan una apuesta epistemológica "porque era una mirada más precisamente de procesos de descomposición y recomposición desde abajo desde la etnografía y otro tipo de sociología más cualitativa". 7 Varios de los autores de este libro posteriormente analizarían la conflictividad social desde la perspectiva de los movimientos sociales, creando y recreando -en diálogo con el debate académico internacional- referencias conceptuales que con los ańos se fueron incorporando en el lenguaje común de varios de los estudios relevados este núcleo temático del PISAC.

Es el caso de Merklen (2005), que en diálogo con el sociólogo francés Robert Castel (1995) introduce los conceptos de: "inscripción territorial", "lógica de los cazadores" y "politicidad popular". Auyero (2002), en diálogo con el sociólogo e historiador norteamericano Charles Tilly, incorpora su teoría de "repertorio de acción colectiva", las nociones de "beligerancia contenciosa", "oportunidades políticas". Svampa (2000, 2008b), en diálogo con el francés Robert Castel, llamó la atención sobre los procesos de "descolectivación de la clase obrera" por los "procesos de descomposición y recomposición social", por la "reconfiguración de la sociedad argentina” y una honda preocupación por tensiones entre la dialéctica de la acción y la estructura en diálogo con Anthony Giddens y Pierre Bourdieu, entre otros. Al llamar la atención sobre estas nuevas referencias conceptuales no pretendemos agotar los aportes realizados por los autores, ni señalar que debatieron solo con las referencias indicadas, queremos apenas aportar algunos de los conceptos y referencias que se fueron perfilando para analizar las hondas transformaciones que se operaban en el período analizado.

A diferencia de la generación intelectual que los precedía, en la cual el trabajo empírico de terreno era menos habitual, estos sociólogos cambiaban metodológicamente el estilo de trabajo. Silvia Sigal (2010), en referen-

7 La cita pertenece a la entrevista realiza a Maristella Svampa. En la misma comenta que como editora de esta publicación tenía el libro terminado en 1998 pero fue publicado en el año 2000 por dificultades con las editoriales. En el mismo escribían entre otros Denis Merklen, Javier Auyero, Gabriel Kessler y Pablo Semán. Todos estos autores se convertirían en referentes ineludibles para entender la conflictividad social en el período que analizamos. 
cia al trabajo de Denis Merklen, realiza una observación que podría ser aplicada a esta generación de sociólogos.

"Encuadrada por las exigencias doctorales, [volvieron] a esa búsqueda de información sobre la sociedad que había sido tan crucial para Gino Germani. Ya no con grandes encuestas de actitudes, financieramente inaccesibles y bajo control de los institutos de investigación de la opinión pública, sino con entrevistas sin reales pretensiones de representatividad. Las corrientes que ensalzaban lo cualitativo frente a lo cuantitativo y el auge de las variantes de la etnología urbana vinieron a legitimar investigaciones cuyos datos son, a menudo, citas de entrevistados, a partir de las cuales se generalizan demandas o temores. El retorno al trabajo de campo y el desplazamiento del foco de interés a las transformaciones sociales y a los nuevos comportamientos colectivos fueron prácticamente simultáneos. Se trataba de repensar la Argentina, de escudriñar las consecuencias de los estragos y de trazar un nuevo mapa social con lo que había desaparecido, lo que había quedado y lo nuevo." 8

El énfasis en la investigación empírica con impronta cualitativa no significó que no se hayan explorados elementos teóricos de la acción colectiva. El grupo investigación de la Universidad de Buenos Aires que tiene como uno de sus principales referentes a Federico Schuster, realizó investigaciones teóricas, empíricas y metodológicas en torno al concepto de "protesta social", lo cual significó revisar las teorías; sistémicas, de la elección racional, la hermenéutica y las postestructuralistas y pragmáticas. (Schuster y Pereyra, 2001; Schuster, Naishtat, Nardacchione y Pereyra, 2005).

Schuster (2005) sintetizaba que la función de la explicación en la reconstrucción de la protesta es la de restaurar la trama de sentido entre la protesta misma y el resto de los acontecimientos sociales. La protesta así no será el resultado necesario de determinadas condiciones estructurales, ni de intereses preestablecidos, ni de identidades dadas, ni de oportunidades o amenazas sistémicas, ni del cálculo de racionalidad costo-beneficio, ni de prácticas de organización previa; pero podrá entenderse de algún modo ligada (conceptualmente, con sentido) a todas estas dimensiones

8 La palabra entre corchetes en nuestra. La cita corresponde al prólogo que Sigal realizó a la segunda edición (2010) del libro de Merklen (primera edición, 2005). 
del análisis o al menos a algunas de ellas. Y esta ligazón podrá proponerse como una interpretación que hipotetiza acerca de relaciones reales en el mundo.

En el período 2007-2012, como señalamos arriba, identificamos un cambio de atención en los objetos de estudio; si en el primer período los principales temas son la crisis de 2001, los movimientos piqueteros y de fábricas recuperadas, en el período 2007-2012 comienzan a asumir centralidad los conflictos y movimientos socio-ambientales, agrarios y los antiguos conflictos territoriales de los pueblos originarios (véase cuadro $\mathrm{N}^{\circ} 1$ ).

\section{Cuadro $\mathrm{N}^{\circ} 1$}

Temas relevados por el PISAC por período en cantidad de estudios

Temas

Crisis de 2001

Piqueteros

Movimientos de fábricas

recuperadas

Movimientos y conflictos

Socio-ambientales

Movimientos y conflictos agrarios

Pueblos originarios

Otros

Total

$$
\text { 2000-2006 2007-2012 Total }
$$

$\begin{array}{rrr}5 & & 5 \\ 22 & 17 & 39 \\ 16 & 12 & 28 \\ 18 & 47 & 65 \\ 10 & 24 & 34 \\ 3 & 10 & 13 \\ 13 & 9 & 22 \\ 87 & 119 & 206\end{array}$

Fuente: base de datos PISAC

A mediados de la década de 2000, los temas e incluso los enfoques teóricos asumidos por los autores relevados están contorneados por los profundos cambios del capitalismo mundial y especialmente el surgimiento de los denominados gobiernos progresistas y de centroizquierda en América Latina. Al observar la región la mayor parte de los investigadores consideró que el levantamiento zapatista del 1 de enero de 1994 inauguró un nuevo escenario de resistencias sociales, que tenía antecedentes históricos inapelables pero que anunciaba las resistencias a una ofensiva neoliberal que aparentaba ser invencible. 
Así la acción colectiva disruptiva que se fue produciendo en varios países latinoamericanos; Guerra del Agua en Cochabamba (Bolivia) en el año 2000, el estallido social en la Argentina en diciembre de 2001, Ecuador en 2005, nuevamente Bolivia en 2003 y 2006, entre otros, fueron colocando en el centro de la escena política a las organizaciones y movimientos sociales como los grandes protagonistas de este nuevo ciclo. Estos movimientos sociales, a través de sus luchas y reivindicaciones, aun de la práctica insurreccional, lograron abrir la agenda pública y colocar en ella nuevas problemáticas: el reclamo frente a la conculcación de los derechos más elementales, la cuestión de los recursos naturales y de las autonomías indígenas, la crisis de representación de los sistemas vigentes, contribuyendo con ello a legitimar otras formas de pensar la política y las relaciones sociales (Svampa, 2008a).

Este cambio habilitó el retorno de ciertos conceptos que habían sido expulsados del lenguaje político y de las academias, tales como "antiimperialismo", "descolonización", o "emancipación”. Un tema que había sido central en la sociología de la década de 1970 volvió a ser discutido, a saber: el desarrollo. El debate asumió una crítica al modelo neodesarrollista con características extractivista y neocolonial. En este contexto volvieron a rehabilitarse las teorizaciones de René Zabaletta y Aníbal Quijano. Mientras que en la discusión internacional la categoría de "acumulación por desposesión” de David Harvey (2003) fue recuperada por varias investigaciones.

Enmarcado en este proceso regional una importante cantidad de producción científica sobre los movimientos sociales se encuentra reunido en el Consejo Latinoamericano de Ciencias Sociales (CLACSO), que en el ańo 2000 crea el Programa del Observatorio Social de América Latina, cuyos resultados aparecieron en la revista $O S A L$, disponible de manera abierta en la biblioteca virtual de esta inmensa red latinoamericana. En la misma se pueden encontrar investigaciones y análisis crítico de los nuevos rasgos del capitalismo latinoamericano; los procesos políticos, sociales y económicos emergentes; y las formas que asumen el conflicto y los movimientos sociales en la región.

Esta no fue la única iniciativa académica: revistas, libros e incluso editoriales se ocuparon de la situación política de América Latina y el papel de los movimientos sociales. Seoane (2003) realizó una compilación en el 
que escribían importantes autores latinoamericanos sobre la situación de los movimientos sociales en la región; Rodríguez Gavarito, Barret, Chávez, editaban en 2005 los trabajos de un importante número de intelectuales para analizar la relación de los movimientos sociales con la nueva izquierda en América Latina. Mirza (2006) realizó un estudio de los movimientos sociales y su relación con los sistemas políticos en América Latina desde una perspectiva comparada en varios países de la región. Korol (2010) en una compilación de dos tomos vuelve a considerar a los movimientos sociales de la región teniendo como principal temática el conflicto socio ambiental y territorial.

La investigación sobre los movimientos sociales en América Latina tuvo escenarios nacionales que ocuparon mayor atención como fueron los casos de Venezuela, Bolivia y en menor medida Ecuador; siendo que el Movimiento Zapatista en México, el Movimiento Sin Tierra (MST) de Brasil y los Movimientos Piqueteros en la Argentina, fueron relacionados como expresiones de un nuevo escenario en Latinoamérica. Una lista de publicaciones se ocupó de estudiar los casos, a saber el de Venezuela, Bilbao $(2002,2008)$ y Luzzani (2008). El de Bolivia, Ceceña (2005), Stefanoni y Do Alto (2006), Svampa y Stefanoni (2007), Svampa, Stefanoni y Fornillo (2010). El zapatismo, Ramonet (2001), Ouviña (2007) y Holloway, Matamoros, Tischler (2008). El caso del Movimiento de los Trabajadores Rurales Sin Tierra y Pizzeta (2009).

La lista de citas bibliográficas hace referencia solo a libros publicados en la Argentina sobre la situación de los movimientos sociales en Latinoamérica y especialmente los casos nacionales y los movimientos sociales antes mencionados. El listado no pretende ser exhaustivo, simplemente llama la atención sobre la importancia que asume la temática y mencionar que esta explosión bibliográfica se reproduce en los países de la región.

En todo el período analizado, un párrafo especial merecen las formas de divulgación y circulación de los materiales sobre la temática de movimientos sociales. La efervescencia social provocada por la crisis de 2001 y el posterior nuevo escenario político latinoamericano creó la necesidad en algunos movimientos sociales, organizaciones, colectivos culturales, movimientos autogestionados, cooperativas, de crear sus propios proyectos editoriales. Vale mencionar algunos casos: la editorial Madres de Plaza de Mayo, ediciones Tinta Limón, editorial LaVaca, editorial El Colectivo, 
editorial Kuruf, editorial Razón y Revolución, editorial Herramienta, entre otros. Cada una de estas editoriales es parte de proyectos más amplios de intervención política, social y cultural y tienen sus librerías y locales de venta. Ligado a esto es importante mencionar que la temática no solo interesa a los especialistas en ciencias sociales, el hecho de que una buena parte de estas publicaciones se pueden encontrar en quioscos, ferias, fábricas recuperadas y cooperativas muestra la atención y arraigo que tiene en sectores que militan en los movimientos sociales.

\section{Los Movimientos Piqueteros y los Movimientos de Fábricas Recuperadas}

Las transformaciones ocurridas en la Argentina -que arrancan en la década de 1970 y se profundizan en la década de 1990- modificaron profundamente su estructura social. Estos cambios dieron como resultado la inestabilidad en el empleo, la degradación de las condiciones de trabajo, el desempleo estructural y la pobreza de importantes sectores sociales.

La consolidación de nuevas relaciones sociales, a mediados de la década de 1990, tuvieron una repercusión importante en el plano de la acción colectiva. Las transformaciones estructurales operadas crearon las condiciones objetivas y subjetivas que posibilitaron la emergencia en la Argentina de un nuevo actor. Se autodenominaron piqueteros y constituyeron una novedad en el escenario político, al menos por los siguientes motivos: a) constituían parte de la clase trabajadora que había sido desplazada como fuerza de trabajo en el nuevo modelo social de acumulación, la novedad fue que consiguieron movilizarse y organizarse para hacer escuchar sus reclamos ante el Estado; b) en el curso de sus luchas habían aprendido que -a pesar de que su fuerza de trabajo no era requerida- disponían de poder, a partir de la capacidad de interrumpir los circuitos productivos poniendo en movimiento un renovado repertorio de acciones colectivas, c) el Estado que, en un primer momento, los había condenado a la invisibilidad social, debió "hacer algo" con esta porción de la clase trabajadora excluida, dado que los piqueteros consiguieron politizar sus necesidades a través de la protesta y la organización colectiva. En suma, los piqueteros surgieron de las filas de los trabajadores desocupados de una 
Argentina devastada por las políticas neoliberales implementadas desde la última dictadura militar y llevadas a su máxima expresión por los gobiernos de Carlos Menem.

Los piqueteros hicieron su primera aparición en la provincia de Neuquén en las ciudades petroleras de Cutral Có y Plaza Huincul en el año 1996. Sin embargo, el punto de inflexión para el naciente movimiento se daría durante el año 1997 cuando los cortes de ruta comenzaron a propagarse por el resto del país de manera abrupta. En este escenario de conflictividad social comienzan a perfilarse los primeros estudios sobre estos movimientos, los cuales no provenían de campo académico sino del campo político y cultural. Dos trabajos muy difundidos sobre la temática en el período analizado fueron el de Oviedo (2001), que realizaba una historia del movimiento piquetero desde la perspectiva del Partido Obrero (PO) y el trabajo de Kohan (2002), que también realizaba una historia a partir de fuentes de prensa de los partidos de izquierda, los diarios nacionales y los documentos elaborados por las incipientes formas de organización. El libro incluía un CD de música del grupo Santa Revuelta, del que formaba parte el autor del libro, con temas alusivos a los piquetes y protagonistas de los cortes de ruta, y fusionaba la cumbia con el rock.

Sin embargo, hay que indicar que en los estudios de los movimientos piqueteros el libro de Svampa y Pereyra Entre la ruta y el barrio, ${ }^{9}$ representa un antes y después en el análisis de la experiencia de las organizaciones piqueteras. Entre los principales aportes los autores identificaban dos afluentes que nutrían al movimiento piquetero. Por un lado, los piquetes y puebladas del interior de la Argentina, resultado de una nueva experiencia social comunitaria vinculada al colapso de las economías regionales y la privatización acelerada de las empresas del Estado realizadas en los años noventa, cuyos casos emblemáticos los representaban las ciudades petroleras de Cutral Co y Plaza Huincul en Neuquén, y Mosconi y Tartagal en Salta. Por otro, la acción territorial y organizativa gestada en el conurbano bonaerense ligada a las lentas y profundas transformaciones del mundo popular, producto de un proceso de desindustrialización y empobrecimiento creciente de la sociedad que arrancó en la década de 1970, cuyo

9 La primera edición es del año 2003, con una inmediata segunda edición actualizada en el mismo año y luego con otra actualización en 2009. 
caso paradigmático se expresaba en La Matanza. Aquí comienza a manifestarse la intervención de actores sociales que habían inscripto su acción dentro de una tradición contestataria más ligada al trabajo en el espacio territorial, en tanto espacio en donde interactuaban diferentes organizaciones de base (sociedades de fomento, juntas vecinales, cooperativas, comunidades eclesiásticas de base, organizaciones no gubernamentales). Así, es la acumulación de una experiencia de trabajo barrial, ligada a la historia de los asentamientos la que va a constituir el núcleo de la acción contestataria y, rápidamente, el punto de partida para la organización de los trabajadores desocupados.

A partir del reconocimiento de las vías de conformación de las organizaciones de movimientos piqueteros los autores identificaron y caracterizaron las diferentes tradiciones que las configuraban: sindical, política y territorial. Posteriormente realizaron un análisis de las relaciones de los movimientos piqueteros con los gobiernos nacionales y provinciales y un exhaustivo análisis de las dimensiones de este actor colectivo, que permitía comprender la heterogeneidad de su composición interna, el protagonismo de las mujeres y la juventud, las configuraciones ideológicas en pugna en su interior y entre organizaciones, y la conformación de las identidades sociales a partir de estas nuevas formas de acción colectiva. En las actualizaciones del libro Svampa realizó un profundo análisis de las diferentes etapas históricas que atravesaron los movimientos piqueteros desde su etapa fundacional en el gobierno de Menem, la centralidad que asumen durante los gobiernos de De la Rúa (1999-2001) y Duhalde (2002-2003), hasta sus relaciones con el gobierno de Néstor Kirchner (2003-2007).

Los estudios sobre movimientos piqueteros, como se puede observar en el cuadro $\mathrm{N}^{\circ} 1$, persistieron de manera constante durante todo el período analizado por el PISAC, con una leve caída durante el período 2006-2012.

Aunque, realizados desde diferentes perspectivas teóricas y disciplinas la mayor parte de los científicos sociales cuyas obras han sido registradas aquí consideró que las prácticas y experiencias piqueteras representaban un fenómeno que iba más allá del corte de ruta o piquete, siendo que en los estudios relevados se investigan algunas dimensiones de los movimientos: el protagonismo de la mujeres y los jóvenes Andújar, 2005; Causa y Ojam, 2008; Espinosa, 2010 y Vázquez, 2011; las formas de construcción 
y prácticas políticas (MTD Solano y Colectivo Situaciones 2002; López Echague, 2002; Mazzeo, 2004), la relación de los organizaciones piqueteras con el Estado (Altschuler y Lecaro, 2002), represión y criminalización de la protesta (MTD Aníbal Verón, 2003; Díaz Muñoz, 2005), la relación ocupados-desocupados (Petrucelli, 2005; Bonifacio, 2009).

Se podría afirmar que la suma de estas investigaciones, la mayor parte estudios empíricos de casos, componen una cartografía de los movimientos piqueteros en la Argentina, especialmente en las provincias de Buenos Aires, Salta y en menor medida Neuquén. Todas las investigaciones asumieron una orientación metodológica cualitativa combinada con el análisis macro social en donde se exponen abundantes datos cuantitativos. Los testimonios de los protagonistas, los documentos políticos, la prensa escrita, incluso fotografías y videos, fueron las principales fuentes de datos para componer los estudios. Desde una perspectiva teórica, una buena parte de los estudios se orientó por la síntesis teórica propuesta por las concepciones de Tilly (1986), Tarrow (2004), McAdam, McCarthy y Zald (1999) o la consideró para realizar críticas a estas perspectivas. El tema también representó un gran desafío para las ciencias sociales, ya que el fenómeno de los trabajadores desocupados que se organizaban y asumían semejante protagonismo político tenía pocos antecedentes históricos. La teoría de la lucha de clases marxista fue asumida en varias investigaciones en la medida en que contribuía a establecer el lugar y las formas asumidas por las organizaciones piqueteras en la dinámica de la crisis del capital.

Un buen ejemplo de esto se muestra en el estudio de Dinerstein, Contartese y Deledicque (2008), en donde en relación a las organizaciones de trabajadores desocupados seńalan: "Ninguna organización puede asumirse como eterna o naturalizarse sino que corresponde a un determinado momento histórico de la lucha de clases. La producción de dichas formas organizacionales es inherente al proceso de valorización del capital, proceso que es continuamente renovado en condiciones cambiantes, lo que 'da lugar a la elaboración continua de formas' [...]. La forma adoptada por la organización de la resistencia en un determinado momento histórico está, entonces, intrínsecamente relacionada con la forma del orden capitalista, su desarrollo y crisis parciales. Esto no significa decir que las nuevas formas organizacionales y de acción colectiva estén 'determinadas por' el desarrollo y/o las crisis capitalistas sino, más bien, que se hallan 
'inextricablemente vinculadas con' las transformaciones del Estado, el dinero, la ley y particularmente a sus crisis, por ende, su significado solo puede evaluarse $v i s-\grave{a}$-vis las formas que adquiere el 'orden capitalista' y sus crisis".

Un importante número de trabajadores resistió la ofensiva neoliberal recuperando las empresas. Desde fines de la década de 1990, pero con particular intensidad a partir de fines de 2001, asalariados de más 200 empresas emprendieron el camino de conducir las fábricas en las que se desempeńaban. La quiebra de la empresa, cierre y/o incumplimiento del contrato salarial fueron las situaciones que desencadenaron, en el marco de una colosal crisis económica, la acción colectiva de los trabajadores. Si bien el movimiento se diseminó por todo el país, se concentró en la zona metropolitana de Buenos Aires. En Capital Federal y el conurbano se concentraron más de la mitad de los casos y en orden descendente le siguieron las provincias de Santa Fe, Córdoba y Entre Ríos.

Este movimiento social se desarrolló en el marco de la crisis económica iniciada en 1998; las cuales provocaron en el sector industrial una reestructuración regresiva caracterizada por la caída en la participación de la actividad en el Producto Bruto Interno (PBI) del país, la concentración y centralización del capital, la reducción de la agregación del valor, la desaparición de la producción local y la transformación de ramas industriales en simples armadurías de insumos importados. Con la recesión, a partir de 1998, muchas fábricas que habían sobrevivido a las transformaciones de 1990, van a entrar en crisis, no pudiendo hacer frente a sus deudas. La profundización de la crisis recesiva paraliza a sectores de la economía y muchas fábricas cierran o trabajan parcialmente incumpliendo los contratos salariales, bajo la sombra de un posible cierre (Rebón y Saavedra, 2006).

En este contexto de colapso y quiebra de numerosas empresas y de generalización del desempleo y creciente pobreza; un conjunto de trabajadores, a los efectos de escapar de la desocupación adoptó la ocupación de las fábricas y luego su recuperación como forma colectiva de evitar un destino que parecía inevitable. El desempleo estructural fue construido como conocimiento por los trabajadores de la experiencia propia o de los familiares, amigos y ex compañeros que les mostraba que fuera de la empresa las posibilidades de encontrar otro trabajo eran muy pocas y si se 
lograba era en condiciones inferiores a las que se poseían originalmente. Además, los años noventa habían enseñado a los trabajadores que las compensaciones legales establecidas por el despido eran magras, la indemnización se terminaba consumiendo y el seguro de desempleo se acababa. Difícilmente en el proceso de remate de la firma los trabajadores terminarían cobrando siquiera una parte de sus acreencias laborales (Rebón y Saavedra, 2006).

Una buena parte de las investigaciones relevadas parten de estudios de casos en donde se indagan los componentes estructurales y las condiciones subjetivas que posibilitaron la ocupación y recuperación de las empresas. No solo la sociología se ocupó de estudiar este movimiento, también campos disciplinarios como la psicología social y de grupos, la economía, la comunicación, la antropología emprendieron estudios desde diversas perspectivas teóricas, aunque una buena parte enfocó el problema desde la teoría de los movimientos sociales. En el análisis de las condiciones estructurales se utilizaron el análisis histórico tanto de las empresas, las trayectorias sindicales preexistentes y el análisis económico y social de la situación crítica que vivió el país posterior a la crisis del año 2001. Para construir sus datos los investigadores utilizaron métodos cualitativos, especialmente entrevistas en profundidad o historias de vida que recuperaban las experiencias de los trabajadores.

Las prácticas sociales necesarias para entender el proceso autogestivo requieren, según Slutzky, Di Loreto y Rofman (2003), considerar las características sociales, culturales y económicas de las personas y grupos que forman parte de los procesos organizativos, e identificar las aspiraciones y motivaciones que lo llevan a integrarse en un marco de experiencias heterogéneas pero con elementos comunes y compartidos que confluyeron a darle forma y contenido a un mismo tipo de organización y actividad.

El fin de la convertibilidad posibilitó utilizar la capacidad industrial instalada en empresas que habían sido, en algunos casos, literalmente abandonadas por sus patrones. La recuperación permitirá poner en funcionamiento a las empresas al disminuir o desaparecer una serie de costos y, lo más trascendente, cambiar los objetivos de la misma: ya no se trata de maximizar la ganancia, sino de obtener condiciones de vida para sus asociados. En este contexto las investigaciones registraron los desafíos que debieron enfrentar los trabajadores para ocupar y luego poner en funcio- 
namiento una fábrica sin patrones y operar en el mercado, esto es enfrentarse a la falta de capital inicial, proveedores que intentan cobrar deudas anteriores o que ya no quieren proveer insumos, dificultades jurídicas, prejuicios contra el cooperativismo, dificultades de acceso al crédito (Rebón y Saavedra, 2006; Magnani, 2005).

Además, la ruptura embrionaria con las formas jerárquicas asociadas a la relación capital y trabajo, permitió la emergencia de espacios de innovación política y social. En un contexto de gran crisis económica y social Rebón (2004: 52) argumenta que "se dejó de esperar que el Estado, el patrón, el puntero político, la autoridad, resuelvan las necesidades de la población. Una porción de la ciudadanía tomó en sus manos lo que no estaba dispuesta a delegar: la reproducción y defensa de la propia identidad social. La acción directa, con una fuerte originalidad y creatividad, fue la forma para realizarla. En los barrios, las asambleas tomaban edificios para instalar centros culturales, comedores o alternativas socioproductivas. Grupos de "sin nada", los piqueteros, ocupaban las calles en reclamo de trabajo y subsidios de desempleo, construyendo emprendimientos autogestivos en sus barrios".

En este escenario, "la autonomización, el ejercicio de nuevos grados de libertad, se expresó como un nuevo avance por parte de algunos trabajadores sobre la dirección de la producción. Así como las autoridades en la sociedad eran cuestionadas, también lo serán las autoridades en algunas fábricas. Los patrones, al incumplir las relaciones salariales y retirarse de la producción en un momento político de crisis general de la autoridad, pasarán también a ser cuestionados". "La crisis política constituye una estructura de oportunidades políticas favorables para la expansión de las recuperaciones. Por una parte, constituye un clima de desobediencia e inconformidad que a va nutrir la posibilidad de desobedecer la determinación capitalista de abandonar la producción. Por otra, crea sensibilidad social para que las recuperaciones se difundan; así, estas empiezan a tener presencia en los medios de comunicación y pasan a ser percibidas positivamente por buena parte de la sociedad" (Rebón y Saavedra, 2006: 22).

Los estudios centrados en los procesos de construcción política en el interior de las fábricas fueron objeto de varios estudios, especialmente las fábricas Zanón y Brukman. Las preguntas que guiaron las investigaciones intentaron dar una respuesta a cómo se desarrollaban los procesos políti- 
cos en el interior de las fábricas, en qué medida la recuperación repercutía en la subjetividad y en representaciones de esos hombres y mujeres, hasta dónde estas respuestas se enlazaban con un proyecto político más amplio (Picchetti y Xiques, 2003; Aiziczon, 2009).

Algunos sectores de las universidades públicas se comprometieron con estas experiencias de autogestión; entre los aportes desde las ciencias sociales merecen destacarse los informes sobre "Relevamiento de Empresas Recuperadas por sus trabajadores" realizados desde la Facultad de Filosofía y Letras (Universidad de Buenos Aires), dirigidos por Andrés Ruggeri. Este grupo de trabajo había desarrollado al año 2010 tres relevamientos generales, en los años 2002/2003, 2004 y 2010 y mantenía en forma permanente el Centro de Documentación de Empresas Recuperadas, que funciona en la Cooperativa Chilavert. El informe correspondiente al año 2010 contiene valiosa información relacionada con la cantidad de empresas recuperadas por los trabajadores (ERT) en todo el país, los conflictos por los que atravesaron (medidas de fuerza, intentos de desalojo, represión, apoyos recibidos), sobre el marco legal en el cual desarrollan las actividades, las formas y el tipo de producción y el estado de las instalaciones, los proveedores, los clientes y las formas de comercialización, la cantidad de trabajadores, las formas de gestión, la cuestión sindical, la seguridad social, las relaciones con el Estado y las formas de organización y solidaridad. Para el ańo 2010, el informe estimaba un total de 205 de empresas recuperadas por sus trabajadores. La fuerza laboral de este conjunto de ERT ocupaba a un total de 9.362 trabajadores y si bien se reconocía que eran un producto de la crisis del año 2001 mantenían la convicción que se sostenían en pie a pesar del desinterés de sectores sociales y políticos.

\section{Los estudios sobre los conflictos socio-ambientales en la Argentina del siglo XXI}

En la Argentina de comienzos del siglo XXI irrumpen en la escena pública una serie de conflictos socio-ambientales que dan cuenta de nuevas formas de la protesta social, demandas que se resignifican (como las luchas por la tierra, las demandas ecológicas, o los derechos indígenas), así como nuevos actores sociales (asambleas de vecinos autoconvocados) que en algunos casos 
se articulan con viejos actores (pueblos indígenas, comunidades campesinas) en pos de objetivos comunes: la defensa de los territorios que habitan y las resistencias sociales frente a diversos proyectos extractivos que usufructúan los recursos naturales y que generan altos impactos socio-ambientales en esos territorios en disputa.

En efecto, tanto la Argentina como América Latina se vieron atravesadas en las últimas dos décadas por la profundización de una tendencia hacia la explotación y extracción acelerada de diversos recursos naturales estratégicos: desde las matrices energéticas fósiles (gas, petróleo y carbón) hasta minerales preciosos como el oro y la plata, pasando por recursos naturales revalorizados - producto de la escasez de las energías fósiles y/o por la crisis ecológica climática a escala global- como el agua, el litio, la tierra (para la producción de alimentos, pero también de agro-combustibles) y las fuentes de biodiversidad (ecosistemas que actúan como reservorios de faunas y floras específicas). Estas actividades "extractivas" sobre los recursos naturales (Giarracca, 2007; Svampa, 2008a y Galafassi, 2009) provocan, por un lado, diversos impactos socio-ambientales sobre los ecosistemas y las poblaciones locales y, por otro, fomenta la tendencia hacia la reprimarización de las economías de aquellos países donde se encuentran estos recursos naturales obturando alternativas creativas de desarrollo que conformen un equilibrio entre las actividades primarias, las industriales y las de servicios de estos países. El extractivismo en nuestro país se expresa fundamentalmente a través de tres actividades: el "agronegocio", la minería a gran escala "megaminería" y las actividades hidrocarburíferas convencionales y no convencionales (Giarracca, 2007; Giarracca y Teubal, 2008; Svampa, 2008a y 2012; Galaffassi, 2009).

Este modelo se ha instaurado en el conjunto de los países de América Latina, conformando lo que algunos autores como Svampa (2012) denominan el "Consenso de los Commodities". Si en la década de los noventa, en plena hegemonía neoliberal, el modelo hegemónico se basaba en el denominado "Consenso de Washington" -decálogo donde se proponían de manera normativa una serie de fuertes reformas del Estado, privatizaciones de empresas y bienes públicos y la desregulación (casi) total de las economías latinoamericanas- en la actualidad lo que se nomina como Consenso de los Commodities "apunta a subrayar el ingreso a un nuevo orden económico y político, sostenido por el boom de los precios internacio- 
nales de las materias primas y los bienes de consumo, demandados cada vez más por los países centrales y las potencias emergentes (...) Este proceso de intercambio desigual no sólo ha contribuido al incremento del precio de los commodities, sino también a generar un creciente efecto de reprimarización en las economías latinoamericanas (Svampa, 2012: 1617). Este consenso, según la autora, opera como modelo hegemónico de desarrollo tanto para los gobiernos que se plantean como continuidad del neoliberalismo (por ejemplo, México, Perú y Colombia) como para aquellos de corte progresista moderados (Brasil, Uruguay, Argentina) como aquellos gobiernos progresistas más radicalizados (Bolivia, Venezuela y Ecuador) y que establece continuidades y rupturas respecto al "Consenso de Washington" en un escenario regional "posneoliberal" (Svampa, 2012). Otros autores, como Borón (2012), no comparten esta caracterización y separan las lógicas productivas y de acumulación de los países con gobiernos "progresistas" de aquellos que continúan con los modelos neoliberales de desarrollo. En efecto, entienden que los primeros utilizan parte de la renta que produce la explotación intensiva de los recursos naturales para establecer modelos de desarrollo que les permitirán avanzar en otras ramas de la economía (como la industria nacional y avances en ciencia y tecnología) a la vez que generan programas de redistribución de la riqueza para los sectores populares de estos países. En este sentido, el autor se pregunta, “¡cómo conciliar la necesidad de responder a las renovadas demandas de justicia distributiva -elevadas por poblaciones que han sufrido siglos de opresión y miseria- con la intangibilidad de la naturaleza? Se trata de una contradicción que antes no existía, debido al atraso de la conciencia ecológica de tiempos pasados" (Borón, 2012: 118).

Frente a este panorama, en toda América Latina diversos movimientos sociales asumen la dimensión territorial-ambiental como eje central de sus luchas, sea desde movimientos ecologistas urbanos, asambleas de vecinos en resistencia a mega-emprendimientos extractivos de diversa índole; o movimientos campesinos e indígenas que resignifican sus luchas por tierra y territorio en una clave socio-ambiental. En efecto, "una de las consecuencias de la actual inflexión extractivista ha sido la explosión de conflictos socioambientales, visibles en la potenciación de las luchas ancestrales por la tierra, de la mano de los movimientos indígenas y campesinos, así como en el surgimiento de nuevas formas de movilización y participación ciudadana, centra- 
das en la defensa de los bienes naturales, la biodiversidad y el ambiente" (Svampa, 2012: 19).

Algunos autores han caracterizado este fenómeno como un proceso de "ambientalizacion" de las luchas sociales (Leff, 2007) que implica un "giro eco-territorial" de los movimientos sociales contemporáneos. La interrelación y construcción de redes de resistencia entre diversos movimientos sociales habilita "la emergencia de un lenguaje común que da cuenta del cruce innovador entre la matriz indígena comunitaria, la defensa del territorio y el discurso ambientalista. En este sentido puede hablarse de la construcción de marcos comunes de la acción colectiva, los cuales funcionan no sólo como esquemas de interpretación alternativos, sino como productores de una subjetividad colectiva" (Svampa, 2012: 22).

Así, las luchas socio-ambientales se transforman en uno de los conflictos característicos del período 2000-2012, los cuales pueden ser definidos como aquellos ligados "al acceso y control de los recursos naturales y el territorio, que suponen, por parte de los actores enfrentados, intereses y valores divergentes en torno de los mismos, en un contexto de gran asimetría de poder. Dichos conflictos expresan diferentes concepciones sobre el territorio, la naturaleza y el ambiente, así como van estableciendo una disputa acerca de lo que se entiende por desarrollo y, de manera más general, por democracia. Ciertamente, en la medida en que los diferentes megaproyectos avanzan de modo vertiginoso y tienden a reconfigurar el territorio en su globalidad, no solo ponen en jaque las formas económicas y sociales existentes sino también el alcance mismo de la democracia, pues se imponen sin el consenso de las poblaciones, generando fuertes divisiones en la sociedad y una espiral de criminalización y represión de las resistencias que sin duda abre un nuevo y peligroso capítulo de violación de los derechos humanos" (Svampa, 2012: 19).

En este sentido, se vienen produciendo diferentes trabajos académicos desde las Ciencias Sociales, así como desde los propios movimientos sociales y ONG comprometidos con estas problemáticas que adquieren una importante relevancia para comprender los procesos de disputas territoriales, los sentidos que otorgan los actores al medio ambiente y la naturaleza que los rodea, las diferentes nociones de "desarrollo" que se encuentran en juego, así como los aspectos macro-estructurales de cada una de estas actividades extractivas y sus consecuencias socioambientales. En este apartado 
abordamos brevemente los resultados alcanzados en algunas de estas producciones que dan cuenta de un fenómeno relativamente novedoso en las Ciencias Sociales pero que adquiere una relevancia social ineludible a la hora de analizar y comprender los conflictos y movimientos sociales socioambientales en la Argentina en particular y en América Latina en general.

Algunos textos académicos han construido miradas integrales acerca de estos conflictos socio-ambientales y por el territorio y los recursos naturales, enmarcándolos en procesos más amplios ligados a la globalización y al avance del extractivismo en toda América Latina en las últimas décadas. El trabajo de Giarracca (2007) -una de las pioneras en abordar estas problemáticas- vincula estas resistencias y estos "nuevos movimientos sociales" con la construcción de las democracias en Latinoamérica. En efecto, el eje de su planteo se traza en torno a las disputas por la apropiación y/o mantenimientos de los recursos naturales, sosteniendo que, si bien las principales acciones y los movimientos sociales emergentes de ese proceso se han convertido en las claves para la comprensión de las luchas sociales contra el modelo capitalista neoliberal en la Argentina y en toda América Latina, estos además son primordiales en la construcción de las democracias de la región.

Se plantea que, desde fines del siglo XX, las disputas más significativas en la Argentina -como en toda la América Latina- empiezan a darse en torno a los "bienes naturales". Esto habría sucedido a partir de que el capitalismo en sus formas neoliberal y transnacionalizada confirió una nueva importancia en su valorización de los recursos naturales. Por ello, en los últimos veinte años surgieron los "procesos de apropiación de la naturaleza dentro de nuevos campos de valorización del capital" (Giarracca, 2007).

Desde una perspectiva crítica a lo largo del texto se van desmontando los supuestos que envuelven la concepción de desarrollo hegemónico, basada en un proyecto cuyo eje central es el progreso técnico, desconectado de las necesidades de las mayorías y al servicio de la pura obtención de ganancias y control social. Los significados otorgados por los países hegemónicos dentro del capitalismo... están centrados en el crecimiento económico y en la metáfora del continuo: "subdesarrollo-desarrollo". En esta vía de análisis, se presentan y caracterizan emprendimientos y proyectos económicos paradigmáticos del proceso de disputa por los recursos y el 
territorio en la Argentina y los que se enfrentan a las transnacionales y a los estados nacionales o provinciales se los conceptualiza como movimientos socioterritoriales. Se analizan los casos de producción minera "a cielo abierto" y las asambleas de autoconvocados contra la megaminería, las papeleras y el surgimiento de las asambleas ambientalistas, el agronegocio sojero y los movimientos indígenas y campesinos en defensa de la tierra y el territorio, poniendo de relieve el tipo de actores que los impulsaron y activan las resistencias organizadas.

En el marco de esos conflictos y disputas, entiende la autora, el significado de los términos "desarrollo" y "progreso" están siendo discutidos. Asimismo, el concepto de "territorio" se anuda a la concepción de "territorialización" que incluye la dimensión cultural, atendiendo a las identidades de las poblaciones que viven en los lugares y que por tanto les asignan sentidos y usos específicos. La orientación teórica del artículo se inscribe en la línea de estudios y epistemologías decoloniales. Adhiere a la noción de "conocimiento desde el sur" del portugués Boaventura de Santos Souza y el concepto de "epistemologías de frontera" de Ramon Grosfoguel, intelectual decolonial puertorriqueño. Retoma los planteos sobre "colonialidad del saber y del poder" del intelectual peruano Aníbal Quijano. Como expresión de la crisis de los paradigmas epistemológicos eurocentrados, sostiene que estas conceptualizaciones llevan a cabo críticas radicales a las miradas modernizadoras y desarrollistas. Asimismo, dialoga con el pensador uruguayo, Raúl Zibechi y con la intelectual de la India Vandana Shiva y se postula una relectura de aportes de Karl Marx. Retoma la noción de "tragedia del desarrollo" de Marshall Berman y la crítica al desarrollo de Gustavo Esteva.

Galafassi (2009), desde una perspectiva marxista heterodoxa que debate y dialoga con la argumentación de Giarracca, aporta importantes elementos para el análisis de estos procesos tomando como eje los conceptos de acumulación originaria de Marx. Revisa aspectos del desarrollo y expansión del capitalismo poniendo en relación las variables capital-trabajo y capital-naturaleza, su dinámica de transformación y crecimiento. Un eje central del trabajo es la comparación entre la acumulación originaria/primitiva, trabajada por Marx, para explicar el despegue y surgimiento del capitalismo, respecto a las formas de la acumulación en el presente. Compara los mecanismos actuales de expropiación y depredación con el proceso primitivo de cercamiento de tierras y expropiación de bienes comu- 
nes. En este sentido, recupera la argumentación de Harvey -también retomado por Giarracca (2007) y Svampa (2012) - de que el capitalismo contemporáneo a escala global se encuentra en una etapa de "acumulación por desposesión" y que esto puede vislumbrarse claramente en los territorios ricos en recursos naturales de América Latina a través del avance de la megaminería, el agronegocio y la frontera productiva de los hidrocarburos en diferentes países de la región en general y en la Argentina en particular.

En este sentido, Galaffassi postula que el proceso de apropiación y separación de los bienes de la naturaleza fue y sigue siendo un mecanismo esencial para el desarrollo del capitalismo, por cuanto provee el soporte necesario tanto en fuerza de trabajo como en libertad de usufructo de los recursos espacio-territoriales presentes. Galafassi recupera de Marx el concepto de trabajo y fundamentalmente lo entiende como un proceso entre hombre y naturaleza, donde el hombre medio, regula y controla su metabolismo con la naturaleza, como relación permanente de intercambio e interacción.

En el marco de estos debates y diálogos fueron instalándose en las ciencias sociales y en los movimientos sociales un conjunto de nuevos temas que son parte de la disputa con las visiones hegemónicas sobre el desarrollo. A manera de síntesis se podrían señalar los siguientes: bienes comunes, soberanía alimentaria, justicia ambiental, "Buen Vivir", derechos de la naturaleza, territorialidad (Svampa, 2012).

Con respecto al Modelo de Agronegocios y las diferentes resistencias sociales frente a su avance en los territorios rurales de la Argentina, contamos con diversas producciones acerca del avance del modelo de agronegocios en nuestro país y sus múltiples impactos sociales, ambientales y en la estructura agraria, así como las diversas resistencias sociales suscitadas en las diferentes geografías donde fue avanzando este modelo.

El texto de Teubal (2001) constituye uno de los principales análisis de las transformaciones recientes de la estructura agraria en relación con la globalización neoliberal. El autor remite a los procesos acaecidos en la década de 1970, tras la crisis de las instituciones de Bretton Woods, donde la globalización se perfila como una nueva etapa en la evolución del capitalismo mundial. Se considera la influencia de este proceso sobre la problemática agraria y agroalimentaria de América Latina, identificando procesos de empobrecimiento e incluso la desaparición de los tradicionales 
actores sociales del medio rural: campesinos, medianos y pequeńos productores agropecuarios, trabajadores rurales. Para caracterizar estos procesos acuña una categoría nueva ruralidad que será considerada en los estudios sobre la conflictividad agraria, ya que el trabajo de este autor presenta un panorama muy bien informado, que se sostiene en el uso de cuantiosas fuentes de información y bibliografía sobre los procesos de transformación y re-estructuración del capitalismo a escala mundial y latinoamericana focalizando el caso argentino. Muestra los flujos y dinámicas de funcionamiento de los mercados, su concentración, las corporaciones, el negocio de las semillas, pesticidas y agroquímicos, el ensamblaje de los distintos eslabones que componen el modelo agroalimentario.

En una línea de investigación similar, el libro de Gras y Hernández (2009) reúne un conjunto de estudios abordados desde una perspectiva interdisciplinar, con trabajos de antropólogos, sociólogos, economistas, geógrafos, agrónomos y politólogos. Se plantea -al igual que en el libro de Teubal (2001)- que existe una relación entre el nuevo modelo de ruralidad globalizada y el desplazamiento de la denominada "agricultura familiar". Se establecen conexiones entre Estado y actores agrarios, estructura social y modelo de acumulación, modelos de desarrollo, donde la soja transgénica -y su expansión geométrica en las últimas décadas- es el emergente de un proceso más profundo, asociado a la globalización del mercado capitalista en los mundos agrarios. Las autoras afirman que en el sector agropecuario las medidas neoliberales significaron el retraimiento del Estado en sus funciones reguladoras (eliminación de una serie de entes de control) y el afianzamiento en su rol de garante del libre juego del mercado. Concomitantemente se plantea que se dejaron de lado políticas proteccionistas y redistributivas, se eliminaron casi todos los impuestos a las exportaciones, se privatizaron las empresas de servicios y se desmantelaron institutos públicos de apoyo técnico al agro, siendo el INTA un caso emblemático. El sistemático trabajo realizado ofrece un panorama de la cuestión agraria que es relevante, debido a que ofrece un panorama descentrado de Buenos Aires, que incluye estudios de provincias del Litoral, del NOA, la región pampeana y patagónica.

Desde ámbitos que combinan la investigación académica con intervenciones ligadas al ámbito del activismo político-social, el Grupo de Reflexión Rural (GRR) viene analizando estas problemáticas desde comien- 
zos de la década del noventa. En el trabajo de Rulli y Boy (2007) - miembros fundadores del GRR- se enfatiza la influencia a la que se somete a la sociedad para que acepte el modelo de los monocultivos, haciendo especial referencia a la soja y cómo este modelo de desarrollo y acumulación se relaciona con profundos cambios en la estructura social agraria, acrecentando el conflicto social (principalmente por la tierra y el territorio), la migración rural hacia las zonas urbanas y la pobreza. El modelo de la soja no se instaló "para terminar con el hambre del mundo y luchar contra los subsidios europeos" sino por la sencilla razón que en "la monocultura de siembra directa" es el cultivo más rentable y fundamentalmente el que requiere una menor utilización de mano de obra.

Desde otra perspectiva -menos crítica del modelo de desarrollo de los agronegocios- el trabajo de Reboratti (2010) plantea que el modelo de desarrollo agrario se impuso por la propia lógica de la producción y el mercado. Las transformaciones agrarias de las últimas décadas en la Argentina se inscriben en una trama donde se combinan distintos factores y aspectos, "la potencialidad natural de la región pampeana y las posibilidades de expansión territorial de un nuevo cultivo con los cambios en los mercados mundiales de alimentos, las nuevas tecnologías agrícolas y el papel de las llamadas nuevas agriculturas". Sostiene el autor que la expansión de la soja tuvo efectos ambientales, sociales y económicos de diversa índole, cuyo alcance y características son actualmente el centro de una acalorada disputa que se ha hecho más dura al incluirse en ella el "factor político", es decir, debates ideológicos en torno a las nociones de desarrollo de diferentes actores políticos del escenario rural, corporaciones empresariales, grupos académicos, movimientos campesinos e indígenas que, en favor o en contra del modelo de agronegocios, fueron irrumpiendo en la esfera pública con debates cada vez más dicotomizados, según el autor, en torno a las ventajas o desventajas de este modelo de desarrollo agrario, anclado en las nuevas tecnologías. El trabajo da cuenta de una importante sistematización y organización de un gran caudal de información, a la vez que propone una periodización de las etapas de expansión y desarrollo del cultivo de soja en la Argentina interrelacionando dimensiones políticas y económicas. Según el autor el modelo se ha consolidado, y no aparecen alternativas viables para reemplazarlo, ya que "todo indica que la soja llegó a la Argentina para quedarse y que en el futuro su predominio se extenderá aún más” (Reboratti, 2010). 
Además de estos trabajos que analizan de manera integral la problemática agraria en la Argentina, donde algunos abordan las resistencias sociales, como Gras y Hernández, 2009 y Rulli y Boy, 2007; existen importantes artículos y libros que realizaron sus investigaciones sobre casos focalizados que dan cuenta de estas transformaciones en diferentes provincias o regiones. Es el caso del trabajo de Álvarez Leguizamón (2012) quien establece vínculos entre un conjunto de variables y dimensiones, proponiéndose analizar la relación entre las nuevas formas de expansión del capitalismo y su lastre colonial, su carácter de colonialidad del poder. Se toma como caso la expansión de los cultivos de soja transgénica en Salta -localizada en la transición entre la yunga y el chaco seco- desde una perspectiva que vincula las formas actuales de producción de pobreza con el desarrollo de los agronegocios. La autora considera los síntomas dolorosos del proceso y paradigmas de las formas de dominación neocoloniales del presente, el caso de las muertes por hambre de niños pertenecientes a los grupos indígenas - de la etnia wichí- que habitan en la zona de expansión de la frontera agropecuaria, postulando que la muerte por hambre en esa zona no sería novedosa sino que se encuentra agudizada por los intensos procesos de expropiación de los medios de subsistencia necesarios para la reproducción de la vida, tales como el agua y el bosque.

Otro estudio de caso que resulta paradigmático para comprender las resistencias sociales en el agro argentino es el trabajo de Schiavoni (2005), el cual analiza las diferentes estrategias de pequeños productores agropecuarios de la provincia de Misiones en su lucha por obtener tierra para producir en el marco de profundas transformaciones de la estructura agraria local y nacional. En este artículo puede vislumbrarse una descripción de las tensiones entre tácticas espontáneas y estrategias organizadas, que operan bajo lógicas diferentes en la ocupación de tierras en grupos de pequeños productores y campesinos del nordeste de Misiones. Ello pone en evidencia las dificultades y limitaciones para la constitución de un sujeto colectivo organizado, como campesino sin tierra.

En lo que respecta a la emergencia de conflictos socio-ambientales en torno a los emprendimientos megamineros, se puede afirmar que desde comienzos de la década de 2000 vienen sucediendo una serie de acciones colectivas de protesta social frente a la denominada "Megaminería" o "Minería a Cielo Abierto". Esta técnica productiva/extractiva se basa en nuevas tecno- 
logías que incluyen la explosión de grandes porciones de territorio montañoso, así como procesos de tratamiento de los minerales obtenidos por medio de estas explosiones altamente contaminantes, sobre todo por el uso de cianuro. Además, estas tecnologías requieren un uso de grandes cantidades de agua en zonas donde, generalmente, ese recurso es escaso y/o es vital para el consumo humano y actividades agropecuarias previamente consolidadas en esas regiones. En localidades cercanas a la zona cordillerana proliferó una diversidad de movimientos sociales -en la forma de asambleas de vecinos autoconvocados contra la megaminería- que protagonizaron diversas acciones colectivas de resistencia contra estos emprendimientos megamineros.

Una multiplicidad de trabajos académicos se abocó a analizar y reflexionar acerca de estas problemáticas. Aquí, considerando la muestra intencional que realizamos, presentamos algunos de los abordajes realizados sobre el tema a sabiendas de que el tema continuaba siendo objeto de variados estudios.

Un libro que sistematiza las resistencias de los movimientos socio-ambientales, y que ha sido una referencia ineludible es la compilación realizada por Svampa y Antonelli (2009). Dentro de ese libro el artículo de Svampa, Solá Álvarez y Botaro (2009) da cuenta de un panorama general de estos movimientos sociales, sus procesos organizativos y sus acciones colectivas durante la década de 2000 en la Argentina. Aquí se proponen abordar lo que entienden como "la compleja y nunca acabada reconstrucción de los diferentes territorios de la resistencia”, su evolución, sus estrategias, sus luchas, en las diferentes regiones y provincias argentinas. Analizan distintos espacios provinciales y regionales como escenarios del conflicto, principalmente San Juan, La Rioja y Catamarca, donde se expresan la gramática de las luchas y dan cuenta del carácter ineludible de estas resistencias, en las que las autoras entienden que se dispersan las "distinciones de clase social, de etnia o experiencia política, unidos por la experiencia vital de defender un estilo de vida y un territorio, en nombre del principio de autodeterminación de los pueblos".

La investigación presenta la importancia económica del sector; según datos de la Secretaría de Minería de la Nación, entre 2003 y 2007 el total de inversiones acumuladas se multiplicó por más de ocho, pasando de 660 millones a 5.600 millones de dólares. La minería metalífera a cielo abierto, beneficiadas por un escandaloso marco legal creado en los ańos noventa y confirmado por las sucesivas gestiones políticas, puso en marcha un "mo- 
delo de desarrollo", a cargo de empresas transnacionales que de manera silenciosa y vertiginosa generan graves consecuencias socioambientales sin siquiera consulta previa a las poblaciones involucradas ni con estudios serios de impacto social, sanitario ni ambiental.

A fines de 2008 el estudio registraba aproximadamente setenta asambleas de base, en más de quince provincias argentinas, que resistían a la par de los proyectos mineros. Estas asambleas articularon sus acciones en un espacio denominado Unión de Asambleas Ciudadanas (UAC); en donde forjaron nuevos repertorios acción colectiva y nuevos formatos de representación.

Sin embargo, la investigación reveló que la convergencia entre carácter defensivo, temporalidad diferente de las asambleas de base y formato asambleario de la UAC (con sus demandas de autonomía y su rechazo, a veces extremo, a la delegación) condicionaban la posibilidad de construir una instancia de segundo grado que potencie los antagonismos existentes en función de una lógica de acumulación política. En este sentido, destacaban la heterogeneidad de su composición, no solo en términos sociales sino experienciales y organizacionales, pues convergían en un plano de igualdad, en primer lugar, mujeres y hombres con ocupaciones y saberes diversos, sin experiencia ni formación política previa; otros con experiencias anteriores y trayectorias militantes (en asambleas barriales, militancia sindical, ecologista, universitaria y/o territorial); en segundo lugar, determinadas organizaciones sociales (territoriales), colectivos culturales independientes y algunas ONG; por último, diferentes organizaciones campesinas e indígenas. Así, desde el inicio la UAC se ha manifestado como un espacio plural, horizontal, apartidario, pero cuyos actores centrales continúan siendo las asambleas y las organizaciones de base afectadas, en la medida en que estas son las protagonistas del conflicto y las encargadas de llevar a cabo las acciones en sus respectivas localidades (Svampa, Solá Álvarez y Botaro, 2009: 135).

Varios estudios de casos contribuyen a componer el mapa de los conflictos en torno a emprendimientos de "minería a cielo abierto", donde los distintos investigadores los abordan desde perspectivas diferentes; en algunos casos divergentes y en otros complementarias.

Machado Aráoz (2011) en un artículo que integra la compilación Bicentenarios Otros, coordinada por Norma Giarracca, analiza los con- 
flictos emergentes del emprendimiento de megaminería en la localidad de Andalgalá (Catamarca). Focaliza su trabajo en la tensión producida ante la expansión extractivista, -la lógica de violencia colonial que la orienta-, y las resistencias sociales que surgen como respuesta ante esa avanzada. En los colectivos de vecinos un principio de creencia basado en el respeto por la vida se vuelve la principal bandera y motor de la lucha. La experiencia de lucha organizada que analiza el texto ancla en la defensa de un modelo de vida que se contrapone al "saqueo colonial". La conformación de la Asamblea de Vecinos del Algarrobo y el enfrentamiento a esa actividad se interpretan como resistencia descolonial emancipatoria que se opone y confronta el modelo de rapiña hegemónico. El saqueo y la violencia colonial son la clave de lectura del empobrecimiento de esa localidad y una expresión de lo que sucede en términos generales en América Latina; "Andalgalá es, desde hace más de doce años, una ciudad sitiada por el conflicto colonial; una sociedad atravesada por la conflictividad estructural que suele instalarse en los territorios de localización de grandes industrias extractivas. Convertida en objeto de deseo por los caprichos especulativos del capital transnacional, ha sido escenario de la confrontación más larga, más intensa y más cruenta que el desembarco de la megaminería transnacional ha provocado en todo el país" (Machado Aráoz, 2011: 281). En este sentido, el autor reafirma la importancia paradigmática de Andalgalá para comprender la dominación colonial ligada a los emprendimientos extractivos; "Andalgalá, lugar de todas las codicias y de todos los dolores, ciudad largamente habitada por el colonialismo-colonialidad del presente, es y fue, una vez más, escenario de todas las violencias. De todas las formas de la violencia colonial: la del terror; la de la expropiación; la de la fetichización" (Machado Aráoz, 2010: 283).

Así, la orientación conceptual de este trabajo se referencia en autores latinoamericanos que adscriben a la línea descolonial o de crítica colonial, como Dussel, Quijano, Santos y Boff, una mirada que, como vimos, replica -en parte- el paradigma teórico utilizado por otros autores.

Por su parte, el trabajo de Wagner (2012) da cuenta de las instancias de audiencia pública para la aprobación de un emprendimiento de megaminería; se propone dar cuenta de los diversos posicionamientos y cuestionamiento generados en Mendoza -específicamente en la locali- 
dad de Uspallata- a partir del proyecto de instalación de la minera San Jorge. Este se convirtió en el primer proyecto que pretendía explotar cobre, oro y plata en Mendoza con la modalidad productiva de "cielo abierto". En este caso, -al contrario del caso presentado en el texto de Machado Aráoz (2010) - se da cuenta de un proceso de resistencia social frente a un emprendimiento megaminero previamente a su realización, en una suerte de "resistencia anticipada". La estrategia que se persigue en el trabajo es la reconstrucción del "conflicto" suscitado en torno a este proyecto. Se analiza en particular la instancia de audiencia pública dado que allí es donde se expresan y manifiestan abiertamente las opiniones de los pobladores -adherentes y opositores al emprendimiento-, pero también los fundamentos de los promotores, técnicos y funcionarios públicos que se posicionan por la afirmativa. Junto a la observación de esa instancia en el abordaje se recurre a la revisión del expediente del proyecto y a la realización de entrevistas a pobladores y otros actores intervinientes en el "conflicto".

En primera instancia, la autora inscribe la posibilidad del surgimiento de un fuerte movimiento de oposición a la instalación del proyecto de megaminería en base a dos fundamentos. Por un lado, a la incidencia e influencia del plebiscito realizado en 2003 en Esquel, que dio como resultado una mayoría opuesta a la instalación de un proyecto de megaminería a cielo abierto. Esto es lo que se ha definido como "efecto Esquel" en el artículo de Svampa, Solá Álvarez y Bottaro (2009). En segundo lugar, la posibilidad del rechazo se basaría en un imaginario ambiental local: "el imaginario de una Mendoza agrícola, que se construyó sobre el "desierto", gracias a la llegada de inmigrantes, al ordenamiento y la distribución del recurso hídrico y a la consolidación de los oasis -que ocupan el 3\% de la superficie, pero en los que vive el $97 \%$ de los mendocinos- está fuertemente arraigado en su población”. En este marco, la llegada de proyectos mineros y el conflicto generado en torno a ellos, puede verse como una disputa por el agua entre el modelo de desarrollo agrícola tradicional -con fuerte arraigo en la cultura e idiosincrasia de Mendoza- y el nuevo modelo de desarrollo minero que iba tomando forma, y que requería de grandes cantidades de agua, siempre escasa en la provincia.

Evaluando el desenlace del proceso la autora analiza los procedimientos políticos-institucionales y su interrelación con una población masiva- 
mente movilizada y de profesionales que revisaron críticamente los informes presentados e impidieron la ejecución del proyecto. El caso analizado permitió visualizar que los argumentos de los vecinos y sus reclamos "se insertaron con fuerza en los procedimientos formales del Estado [...] evidenciaron la importancia del accionar de la sociedad en torno a estos conflictos de carácter 'socioambiental', que radica en su capacidad de desafiar e influir en los procesos institucionales de participación y de poner en tela de juicio la legitimidad de las decisiones tomadas por el mismo Estado" (Wagner, 2012: 214).

Con respecto a los hidrocarburos, en los últimos años emergieron -en el marco de cambios tecnológicos en la actividad hidrocarburífera- nuevos los procesos de resistencia social a estas tecnologías de explotación de gas y petróleo - "fractura hidráulica" o "fracking"- que se realizan en los denominados yacimientos no convencionales. Por ser un fenómeno de reciente aparición, no existen aún muchos trabajos de índole estrictamente académica en el período aquí abordado (2000-2012). La región donde se han desplegado principalmente este tipo de explotaciones ha sido el yacimiento "Vaca Muerta" en la provincia de Neuquén y en algunas regiones del Alto Valle de Río Negro. En este sentido, el trabajo realizado desde el "Observatorio Petrolero Sur" aparece como pionero en el análisis crítico de esta problemática en torno a los impactos sociales y ambientales del fracking en estas regiones. De este modo, el trabajo de Di Risio, Pérez Roig y Scandizzo (2012) presenta una perspectiva crítica frente a lo que los autores definen como una "voracidad energética del capitalismo", destacan que la Argentina ya cuenta con una significativa infraestructura que facilitaría la producción y la exportación de gas natural. A tales efectos, la cuenca con mayores perspectivas es la neuquina, ya que combina una tradición de prácticamente cien años en la explotación de hidrocarburos, con formaciones geológicas -sobresale la de Vaca Muerta- para el desarrollo de explotaciones de tight gas y shale gas. De este modo, la fuerte incidencia de los combustibles fósiles en la matriz energética argentina, la necesidad económica de las provincias de obtener "recursos genuinos" avanzando hacia la profundización del modelo extractivo y la creciente demanda global de energía, son las variables que se imponen con más fuerza. En este escenario, una vez más los costos socioambientales de la explotación de yacimientos no convencionales han quedado fuera de la dis- 
cusión por parte de los funcionarios del Estado y las empresas, quedando en manos de las organizaciones populares forzar la discusión sobre ese punto e impedir la agudización de un régimen de producción y consumo de energía social y ambientalmente insustentable.

En la actualidad existen distintas líneas de investigación desde la Ciencias Sociales que se encuentran abordando los impactos sociales y ambientales del fracking en la Argentina contemporánea, así como los procesos de resistencia y movilización que se dan frente a este avance de la frontera hidrocarburífera. Gran parte de estas producciones comenzaron a publicar sus resultados preliminares en años posteriores al relevamiento realizado desde el PISAC (Pérez Roig, 2012; Bacchetta, 2013; Svampa y Viale, 2014; Schweitzer, 2014; Bertinat et al., 2014; Di Risio y Cabrera, 2014).

Otros conflictos socioambientales que han acontecido en la última década en la Argentina se encuentran asociados a la ampliación de los emprendimientos forestales y las pasteras; la construcción de represas -en este caso los conflictos aparecen en décadas anteriores como, por ejemplo, en torno a la represa de Yaciretá- que anegan amplios territorios donde son desplazadas pequeñas poblaciones rurales, campesinos y/o indígenas; y, por último pero no menos importante, existe también una diversidad de conflictos socioambientales ubicados en zonas urbanas y periurbanas que se han desplegado desde la década de 1970 en adelante, ligados a la cuestión de los residuos sólidos urbanos (RSU), refinerías y otras industrias contaminantes, contaminación de ríos, arroyos y otras fuentes de agua, inundaciones, avance urbano -ligado a la especulación inmobiliaria- por sobre humedales, bosques, islas y otros espacios con biodiversidad ambiental, entre otros casos. Estos conflictos son una parte importante de la conflictivdad ambiental de la Argentina contemporánea, no ligado a actividades extractivas pero que también han generado importantes procesos de acción colectiva y movilización social completando el mapa de los movimientos sociales "ambientales", tanto en áreas rurales como urbanas que aún se encuentra en construcción, cuestión que ha sido relevada por una vasta bibliografía de las ciencias sociales (Auyero y Swistun, 2006; Bañuelos, Mera y Rodríguez, 2008; Carman, 2011; Di Virgilio, 2011; Pintos y Narodowsky, 2012; Merlinsky, 2013, D’Hers, 2013; Azuela y Cosacov, 2013). 
$\mathrm{Al}$ respecto, el trabajo de Seoane y Taddei (2010) da cuenta del conflicto suscitado alrededor de la instalación de diversas pasteras en la cuenca del Río de la Plata, de las cuales la más paradigmática es la de Botnia sobre el río Uruguay, en la costa uruguaya frente a la ciudad argentina de Gualeguaychú. Este trabajo, que integra la compilación: Recolonización, bienes comunes de la naturaleza y alternativas desde los pueblos, tiene un enfoque ensayístico ligado a las ciencias sociales críticas. Presenta una breve reseña del "conflicto" derivado de la instalación de la planta de celulosa en la localidad de Fray Bentos. Tal conflicto, públicamente conocido como "caso Botnia” representa para los autores una manifestación de la difusión de los monocultivos que responden a un modelo forestal globalizado. El texto presenta, desde un posicionamiento crítico, los efectos y consecuencias derivadas de ese emprendimiento, encuadrado en proyectos industriales de producción de pasta papel. Se atribuyen, entre otros efectos de esta actividad extractiva, la privatización y concentración de la propiedad de la tierra en mano de empresas extranjeras, originando una suerte de latifundio sin precedentes en la historia de Uruguay.

En este sentido, los autores afirman que "el alerta y la oposición a los riesgos y las consecuencias de esta industria impulsaron, desde las acciones de la Asamblea Ambientalista de Gualeguaychú, el desarrollo de un poderoso movimiento social ambiental en ambos países [...] Estos movimientos alertaron tempranamente contra los problemas provocados por la desposesión de tierras y la deforestación, por el tamaño y la capacidad de producción de estas usinas, por el efecto de las emisiones de gases, por los problemas derivados de la producción de los agentes de blanqueo y por los vertidos y la contaminación del agua" (Seoane y Taddei, 2009: 60). Otros trabajos muy relevantes para el caso de la construcción de la pastera sobre el río Uruguay son los trabajos de Palermo y Reboratti (2007), Merlinsky (2008) y Delamata (2009), que fueron señeros para los debates académicos que provocaron las acciones colectivas del pueblo de Gualeguaychú y otras ciudades de Entre Ríos que se opusieron a la construcción de la Empresa Botnia en la localidad uruguaya de Fray Bentos.

Con respecto a los conflictos en torno a las represas hidroeléctricas, el caso más importante de la Argentina contemporánea es el de Yacyretá. El trabajo de Barone y Ruiz Díaz (2011) da cuenta de la conformación de una de las organizaciones de afectados por la construcción de la represa 
hidroeléctrica de Yacyretá; para ello se remonta a la década de 1980, momento de inicio de estos grupos. Se identifican por entonces los primeros reclamos organizados, diferentes manifestaciones -desde las carpas, cortes de ruta, hasta presentaciones formales judiciales-, que habrían sido movilizadas por la población afectada y contando en ocasiones con el apoyo de organismos provinciales o municipales. Se plantea que, como resultado, de esas incipientes acciones, se fueron organizando las primeras comisiones vecinales, con el objetivo de ir delineando posibles soluciones para los grupos de población directamente afectada y a otros semejantes, a quienes se los excluía del derecho a la compensación por los daños. Se identifican en este marco la situación de exclusión social y territorial en un entramado clientelar alrededor de las familias damnificadas. Las principales referencias teóricas se encuentran en la teoría de los nuevos movimientos sociales, se dialoga con Touraine (1987) y Melucci (1994) en torno al concepto de movimiento social. De este último autor toman la propuesta de analizar un movimiento social reconociendo que en el fenómeno de la acción colectiva tres elementos básicos: Solidaridad, conflicto y tendencia a romper los límites del sistema al que se orienta la acción.

Con respecto a los conflictos socioambientales de las zonas urbanas y periurbanas, el texto de Merlinsky (2008) da cuenta de estas problemáticas a partir del análisis de dos casos en la cuenca baja del río MatanzaRiachuelo (sur del Área Metropolitana de Buenos Aires) que remiten a experiencias y trayectorias organizativas ligadas a la gestión de recursos naturales y manejo de conflictos ambientales. El centro del interés está puesto en la irrupción de organizaciones sociales de carácter territorial de vecinos que surgen con una voluntad comunitarista y de fomento que en la última década se reconfiguran organizándose como redes que contienen una agenda más amplia-que incluye problemas ambientales y de gestión de recursos naturales, específicamente agua y residuos urbanos- a escala y con alcance regional (procesos de reacomodamiento de los agrupamientos territoriales existentes y sus respectivas articulaciones en torno a la constitución de nuevos escenarios de presión y negociación). De ese modo logran introducir sus reivindicaciones en las agendas locales y municipales, politizan así la esfera territorial y plantean que son ciudadanos que residen en territorios con "desventaja ambiental". Proceso en el cual articularon demandas con otras organizaciones del conurbano bonaerense constru- 
yendo lo que la autora define como "región de enunciación" que nuclea diversos territorios con problemáticas ambientales comunes.

Los casos de estudios son el conflicto por la desafectación del relleno sanitario de "Villa Domínico" (municipios de Quilmes y Avellaneda) y "Foro Hídrico" (en el municipio de Lomas de Zamora) que articulan demandas en torno a la gestión de agua potable y la prevención de inundaciones en los barrios de la zona. Se destacan algunos elementos importantes que dan cuenta de estas formas de acción colectiva: 1) El proceso de creciente organización de los grupos de pobladores y el incipiente nivel de articulación entre organizaciones se da en el contexto de un cambio en la estructura de oportunidades políticas (el escenario de creciente conflictividad social posterior a los episodios de diciembre de 2001);2) Las principales propuestas y sugerencias de cambio en los modelos de gestión institucional de los recursos naturales en los años 2002-2004 en la región bajo estudio, son producto de la iniciativa de las organizaciones sociales, antes que del Estado; 3) Los conflictos y la construcción de consensos; son expresiones de relaciones de poder, antes que resultado de la aplicación de mecanismos racionales de resolución de conflictos; 4) Lo característico del proceso de agregación de demandas en este caso es que los diferentes grupos de acción en el territorio fueron articulándose y re-articulándose a lo largo del tiempo utilizando mecanismos flexibles y adaptativos que siguen la lógica de un agrupamiento de varias organizaciones y el cambio del contexto político.

\section{Estudios sobre pueblos originarios y luchas territoriales}

Buena parte de la producción académica de la última década ha dirigido sus análisis en algunas de las dimensiones implicadas en el complejo proceso que envuelve la revisibilización de los pueblos originarios en el país. Los debates principales giraron en torno a lo que se denominó re-emergencia o revitalización étnica -desde distintos encuadres teóricos-, alrededor de ello se concentraron los debates teniendo como eje los límites y alcances de la creciente autoadscripción o autoidentificación y el reconocimiento de derechos hacia los pueblos indígenas.

En el trabajo que constituye una referencia insoslayable en el tema, José Bengoa (2000) analiza la reemergencia indígena como un fenómeno propio 
de los años noventa y cuya expansión abarca toda América Latina. Indaga las condiciones específicas de posibilidad que lo habilitan y su extensión y escala espacial. Identifica tres elementos relativos al contexto internacionalmundial que, desde su perspectiva, aportarían a explicarlo: la globalización (que en todas partes del mundo va acompañada de una valorización de las relaciones sociales y de las identidades locales), el fin de la Guerra Fría-que habría posibilitado la existencia de movimientos sociales que no se identifican ni con el comunismo ni con el capitalismo sino con utopías arcaicas, las hondas raíces culturales de América Latina-, y el tercer factor explicativo estaría en los acelerados procesos de modernización que experimentaron los países del continente desde mediados de los años ochenta. Según las evaluaciones de este autor, ello habría dejado como consecuencia una menor presencia del Estado y una crisis profunda de las ideas de ciudadanía sustentadas por los gobiernos durante más de cuarenta años (Bengoa, 2000: 23). Desde tal óptica, la modernización en América Latina trajo aparejada la regresión en la distribución del ingreso y la acentuación de las diferencias entre ricos y pobres. Las ideas de desarrollo, a la que se apela frecuentemente, toman como punto de partida el supuesto de sociedades homogéneas -desconociendo la historia latinoamericana y por ende la complejidad de sus sociedades-. Los procesos de globalización se presentan, a su vez, como productores de la heterogeneidad interna que genera nuevas formas de exclusión. Ese proceso de modernización es identificado como el punto de quiebre de los "mecanismos integrativos" propios de los Estados nacionales, y como consecuencia de ello emergen y se tornan visibles las demandas por los derechos civiles indígenas.

Tal como el autor sostiene, la emergencia indígena a partir de los años noventa debe enmarcarse en la contradicción que se genera entre la exclusión económico-social y la afirmación de una nueva identidad étnica (2000: 49). Para Bengoa, el fenómeno de la reemergencia étnica va acompanádo del surgimiento o instalación de "la cuestión indígena" en la agenda pública. Toledo Llancaqueo (2005), por su parte, ofrece una hipótesis para comprender esa "irrupción" de los indígenas como actores políticos en los países latinoamericanos. Este suceso se enmarcaría en lo que el autor entiende como el fin de un ciclo -el del reconocimiento- y el inicio de otro -el de los derechos territoriales- dentro de la trayectoria de los conflictos etnopolíticos en el continente. Según su perspectiva los derechos territoriales 
han ganado renovada actualidad frente a las transformaciones de una geopolítica neoliberal. El ciclo que comprende entre los años 1990 y 2003, fechas que operan como parte aguas simbólico al remitir a hitos de visibilidad a escala continental, está marcado por las contiendas en torno a los derechos indígenas y los conflictos etnopolíticos. Este ciclo es fundante de las contiendas indígenas del siglo XXI en América Latina, en él tiene lugar "la constitución de los movimientos indígenas como actores políticos nacionales y transnacionales desde donde decanta una agenda de derechos de los pueblos indígenas... movimientos que lograron poner en el centro del debate público, con distinta intensidad, sus reclamos de reconocimiento como colectivos diferenciados..." (2005: 68).

El autor entiende que hay un conjunto de aspectos que estarían sintomatizando el agotamiento o fin del ciclo de reconocimiento a los pueblos indígenas. Particularmente, advierte que los balances de puesta en práctica de esos derechos han mostrado sus imperfecciones, insuficiencias e inadecuaciones, así como se han visto debilitados o anulados derechos en lo que respecta a la territorialidad frente al avance de regímenes sobre el libre comercio y medio ambiente.

La territorialidad remite a los derechos de propiedad, acceso y control sobre tierras, recursos naturales y biodiversidad, todo lo que constituye el núcleo duro de los derechos colectivos, y por tanto delinea el eje sobre el cual se articulan los reclamos en el nuevo ciclo, el de los derechos territoriales indígenas. Marcados estos por los procesos de globalización y neoliberalismo, en tanto que "la globalización económica compromete de sobremanera a los territorios indígenas por la intervención de las empresas transnacionales, vía mega proyectos y enclaves" (2005: 80). El punto central del argumento de Toledo es, en ese sentido, que los procesos contemporáneos tienen otros impactos territoriales, distintos a los ciclos previos del capitalismo, "la dinámica de espacio y tiempo bajo el esquema del Consenso de Washington tiene como rasgo característico la capacidad de modificar incesantemente las territorialidades (2005: 82). La capacidad de crear y modificar los órdenes espaciales sería constitutiva de todo proceso histórico y modelo económico, aunque asume en la globalización "un nivel cualitativo distinto, pasando a ser uno de sus rasgos propios la incesante creación, modificación y periclitación de territorialidades (2005: 82). Se sostiene que a partir de las reconfiguraciones territoriales surgieron 
los principales reclamos indígenas, tornándose la "tradicional" lucha por la tierra en reclamo territorial y de derechos autonómicos (2005: 84). Viraje mismo que demandó la adecuación de los instrumentos conceptuales para abordarlo. Postula Toledo que la complejidad implicada en el denominado "giro territorial" requiere considerar múltiples dimensiones y los diversos sentidos que asume la noción de territorio: como jurisdicción, como espacio geográfico, como hábitat (conjunto sistémico de recursos), como biodiversidad y conocimiento (expresión de derechos de propiedad intelectual) y como espacialidad socialmente construida en vínculo con la historia y la identidad (2005: 87). Concluye esta propuesta en que las contiendas indígenas del presente son explícitamente etnoterritoriales, de defensa y reconstrucción de los territorios indígenas, "contiendas que emergen en etnoterritorios que se ven amenazados o fracturados [...] la multiplicación de las contiendas etnoterritoriales se intensifican, emergen y multiplican por la fuerza de los hechos, por los impactos de liberalización económica [...] contiendas que son al mismo tiempo transnacionales y territoriales" (2005: 94).

Este fenómeno ha sido encarado desde distintos encuadres teóricos dando lugar a sendos debates respecto a la pertinencia de entenderlos y definirlos como reemergencia o revitalización étnica. Entre otros autores, Briones y Ramos (2010) discuten el uso de la noción de re-emergencia y su pertinencia para el caso argentino, en tanto entienden que obtura la comprensión de estos procesos en su larga duración y gestación, ya que los pueblos indígenas por cerca de 200 ańos -y de modo ininterrumpidohan sostenido reclamos y demandas, ante las autoridades coloniales primero y republicanas después, por sus tierras comunales, aunque estas se expresarán por vías singulares o mediante mecanismos judiciales sin generar directamente visibilización pública. Por ende, asumir la actual expresión como una re-emergencia es desconocer o subvalorar la continua y profunda historicidad de esos reclamos.

Otro aspecto, particularmente controversial, es el caso de pueblos indígenas que desde las narrativas oficiales de "la Nación” y también los discursos históricos provinciales se daban por desaparecidos o extintos, en el marco del proceso que Briones (2005) definió como formación de alteridades, tanto en el espacio nacional como hacia dentro de las provincias. Entre tales casos puede señalarse el de los grupos huarpes (San Juan y 
Mendoza), ranqueles (La Pampa) y diaguitas (Salta, Tucumán, Catamarca y Santiago del Estero), quienes experimentan una notable visibilidad en el presente y han alcanzado importantes niveles de organización política -comunitaria, en espacios supracomunales, uniones interprovinciales y redes nacionales-. Sin embargo, y aunque cuentan con el reconocimiento legal como pueblos y comunidades indígenas y accedieron al otorgamiento de sus respectivas personerías jurídicas -y a cargos de representación en agencias estatales-, su autenticidad es frecuentemente puesta en cuestión o sospechada y por tanto debe ser robada, tal como muestran los trabajos sobre los ranqueles de Lazzari (2007 y 2010), sobre los huarpes (Escolar, 2007), kollas (Karasik, 2010), tapietes (Hirsch, 2010), diaguitas (Sabio Collado, 2013). Frente a esta paradoja los distintos pueblos o naciones indígenas han ido construyendo o fijando lo que Escolar (2007), desde el estudio del caso de los huarpes definió como estándares de autenticidad. Desde y a través de estos se demarcan criterios y parámetros indicativos de una auténtica y verdadera indianidad.

Distintos estudios indagaron sobre tales aspectos enfatizando en el carácter problemático y complejo de las políticas de reconocimiento, que desde las agencias estatales -y estructurados en base a una lógica y racionalidad específica- prefigura el modo y la forma no solo mediante los cuales los pueblos indígenas deben expresar su diferencia o particularidad cultural sino también ciertos itinerarios y procedimientos a través de los cuales validarse institucionalmente como tales. De cierto modo estas problematizaciones condujeron a que buena parte del debate contemporáneo se concentre en las relaciones entre Estado y Pueblos Indígenas. Algunas perspectivas pusieron el foco sobre las políticas estatales, el marco jurídico y su instrumentación mientras otras al nivel de las prácticas políticas, las modalidades de acción y de formación de colectivos indígenas. Los trabajos de Tamagno (2014) y Briones (2015) con matices y enfoques diferentes realizan balances y evaluaciones respecto a los límites y alcances de las políticas estatales de la última década dirigidas a los pueblos indígenas. Particularmente el trabajo de Briones analiza los efectos de las políticas indigenistas sobre el movimiento indígena y se propone discutirlo desde la clave de la transformación en los estilos de construcción de hegemonía cultural que signaron la dinámica de los últimos diez años. 
Este escenario, que presenta rasgos comunes y a la vez matices propios en la geografía múltiple que compone el actual espacio nacional, es llamado con cierta ironía: "el florecimiento de los pueblos indígenas" o "la primavera étnica", enfatizando en la aparición de "nuevos" grupos indígenas y en la multiplicación de comunidades identificadas con diversas etnias. Distintos autores coinciden en remontar este proceso a la década de 1990, momento en que el fenómeno empieza a activarse en todo el continente -como ya antes se señaló-, y numerosas organizaciones indígenas comienzan a idear estrategias organizativas y a crear espacios y ámbitos de representación alternativos a los existentes hasta entonces. Asimismo, fue que se planteó una agenda política diferente, de carácter más confrontativo, apuntando a solucionar los "problemas estructurales", de ello que la cuestión territorial fue constituyéndose en el tema central. Esto fue recientemente destacado por Radovich, quien afirma que "las distintas organizaciones indianistas de las provincias argentinas, en su gran mayoría, plantearon una política de duro enfrentamiento con los gobiernos provinciales y nacional, ante el embate de las políticas económicas neoliberales implementadas durante el decenio (1989-1999), gobierno del presidente Carlos Menem" (2014: 137-138).

En los años noventa, mientras empiezan a cobrar notoriedad las demandas indígenas mediante la instalación pública del acceso y derecho a la tierra como la problemática social de mayor urgencia, mediante la reforma de la constitución de 1994 -y específicamente el artículo $75^{\circ}$ inciso 17- se habilita un nuevo marco jurídico para encuadrarla. Este hecho es considerado como un hito indiscutible en el plano jurídico, en lo que respecta al reconocimiento de derechos hacia los pueblos originarios. En distintos estudios, entre otros Radovich, (2014), Gordillo y Hirsch (2010) y Gorosito Kramer (2008), se retoma parte de los fundamentos de la ley que afirman: "Reconocer la preexistencia étnica y cultural de los pueblos indígenas argentinos. Garantizar el respeto a su identidad y el derecho a una educación bilingüe e intercultural; reconocer la personería jurídica de sus comunidades, la posesión y propiedad comunitaria de las tierras que tradicionalmente ocupan; regular la entrega de otras aptas y suficientes para el desarrollo humano; ninguna de ellas será enajenable, transmisible ni susceptible de gravámenes o embargo. Asegurar su participación en la gestión referida a sus recursos naturales y a 
los demás intereses que los afecten. Las provincias pueden ejercer concurrentemente estas atribuciones".

Según sostienen Gordillo y Hirsch (2010), la reforma de la constitución de 1994 galvanizó un notable nivel de militancia indígena que desde 1992 y como parte de la campaña contra los festejos por el quinto centenario del "descubrimiento de América", propició debates que incrementaron la visibilidad pública de estos grupos, facilitándose así la articulación de nuevas luchas. A nivel continental también suceden hechos de notable trascendencia que aportan en esa dirección, como el levantamiento armado del Ejército Zapatista de Liberación Nacional -en Chiapas, México, enero de 1994-. Organización compuesta por comunidades indígenas de las distintas etnias que habitan el sureste mexicano.

Los antecedentes de las organizaciones indígenas en la Argentina, como Gordillo y Hirsch (2010) plantean, remontan sus orígenes a mediados de los años setenta, cuando dirigentes y militantes indígenas comenzaron a demandar un nuevo marco legal para la adquisición de derechos a nivel nacional, iniciándose así un largo proceso y camino de organización.

Los distintos diagnósticos sobre la actualidad de los pueblos indígenas coinciden en que la lucha por la tierra es un problema histórico en la $\mathrm{Ar}$ gentina y que está ligado al modo en que se entablaron los vínculos fundantes entre Estado y pueblos indígenas. Se ofrecen y proponen periodizaciones de acuerdo al foco que plantea cada autor. Algunos postulan una organización en fases que se remontan al último cuarto del siglo XIX y que marcarían el desplazamiento desde un plan de exterminio y persecución hacia una especie de "inclusión subordinada", "integración" o reconocimiento. Sin embargo, y a pesar de que se modifica el escenario a lo largo del siglo XX y principios del XXI, es común que se afirme que este constituye un conflicto que no solo no ha sido resuelto, sino que además alcanzó magnitudes y efectos inusitados.

Hay importantes hitos en ese sentido, ligados a las movilizaciones que en la década de 1990 abrazan un importante conjunto de demandas entre las cuales "el conflicto de tierra" va cobrando centralidad y agrupa a diferentes pueblos y etnias, entre ellas las comunidades wichí de Salta. Estas, particularmente, inauguran la práctica de los cortes y bloqueos de rutas al mantener interrumpido por más de 20 días -entre agosto y septiembre de 1996- el tránsito del puente internacional Misión La Paz-Pozo Hondo. A 
este suceso se han referido Carrasco y Briones (1996) en el trabajo La tierra que nos quitaron, publicación que constituye una referencia obligada sobre el proceso organizativo del pueblo wichí y también ha sido analizado por $\mathrm{Bu}-$ liubasich y Rodríguez (1997) y Gordillo y Leguizamón (2002). El formato que asumirá aquella protesta en el transcurso de la década posterior se generalizará cuando los piquetes se extiendan a lo largo de todo país y se expresen fuertemente en las cercanas localidades de General Mosconi y Tartagal.

El gobierno de Néstor Kirchner y el diseño de específicas políticas públicas crea un nuevo escenario a partir del que se re-definen la forma y los términos del relacionamiento entre Estado y colectivos sociales y, particularmente, entre Estado y organizaciones indígenas.

El Censo Nacional de 2003, que en su cuestionario incluye la posibilidad de la auto-adscripción indígena, es una expresión de ese nuevo marco de relacionamiento entre Estado y pueblos indígenas.

Hecho que se inscribe en un conjunto de gestos políticos, acciones simbólicamente significativas y que a nivel discursivo sostienen consignas como "la reparación histórica" del Estado nacional con los pueblos originarios. Desde la perspectiva de analistas sociales, como Gorosito Kramer (2008), estos gestos se consideran insuficientes, pues se entiende que el marco de reconocimiento no tuvo incidencia directa sobre las condiciones materiales de vida, y que los problemas y conflictos de acceso a la tierra y a los recursos naturales en general no han sido resueltos.

Desde una perspectiva afín, Tamagno mira con preocupación "la contradicción entre un mayor reconocimiento de las presencias indígenas junto a una valoración positiva de su visibilidad por un lado y por el otro la imposibilidad de que los reclamos por tierra, vivienda, educación y salud sean satisfechos. Una visibilidad que, es importante reconocer, no es ajena ni a la trayectoria de lucha del movimiento indígena en su conjunto, ni a los espacios generados por las políticas estatales en respuestas a las demandas de los pueblos indígenas" (2014: 13).

Así, son coincidentes los señalamientos acerca de que en este período en el que sucedieron los mayores avances formales -en materia de reconocimiento legal de derechos- igualmente se incrementaron los reclamos y denuncias por violaciones de estos mismos derechos. Inscriptos en el avance de la frontera agropecuaria y principalmente del monocultivo de soja, que se expandió por sobre territorios que en algunos casos están efec- 
tivamente bajo ocupación y uso de pueblos indígenas y en otros están siendo objeto de reclamo por parte de estos. Las principales consecuencias de ese avance ya fueron reseñadas en el apartado 5 de este capítulo, y se enmarcan en procesos definidos como de "desposesión" o "neocolonialismo", que provocan el desalojo de grupos que bajo derecho consuetudinario y por varias generaciones hicieron uso de la tierra sin poseer documentos legales que los amparen como "propietarios" u ocupantes. La dinámica de adquisición de las tierras tiene la forma de una marcada concentración de grandes extensiones en manos de un reducido grupo de propietarios, que en algunos casos integran consorcios y corporaciones empresariales de capitales internacionales, lo cual se inscribe en el cambio de paradigma y de modelo que tuvo lugar en la última década con los "agrobussines" y la "sojización". Con la presencia de estos actores se agudizaron los problemas no solo por la tierra sino también por otros recursos, por el acceso al agua y su distribución, a la par de los daños ambientales provocados por los desmontes y la tala indiscriminada de bosques nativos. A modo de ilustración basta retomar lo advertido en relación a las muertes producidas en el seno de disputas por la propiedad, reconocimiento o titularidad, en instancias de desalojos o ante el intento de frenar desmontes.

En el sentido de lo antes dicho, Radovich planteó que "en algunas provincias el enfrentamiento entre organizaciones y los gobiernos provinciales ha conducido a formas de violencia y de represión de las protestas con marcada virulencia (asesinatos impunes, judicialización de los reclamos, procesamiento de dirigentes, manipulación del miedo, desalojos compulsivos y usurpación de territorios). Todo ello en un marco de manipulaciones informativas cuya base argumental en algunos casos suelen ser diversas formas de racismo y etnofobia como expresiones de intolerancia y discriminación (Radovich, 2014: 141).

En parte, como resultado de la presión y demanda de los colectivos indígenas y campesinos y también por la sostenida denuncia mediática en 2006 se declara "Emergencia territorial en materia de posesión y propiedad de las tierras ocupadas por las distintas comunidades indígenas del país" mediante la sanción de la Ley 26.160, prorrogada en dos ocasiones (2009 y 2013). Se establece allí que no podrán efectuarse desalojos hasta tanto se concluyeran las tareas de relevamiento territorial (técnico, jurídico y catastral) en todas las provincias de los territorios reclamados por 
las comunidades. Labor que entonces se encomienda al Instituto Nacional de Asuntos Indígenas - creado a mediados de la década de 1990-. Tal como sostiene Radovich (2014), y plantean principalmente dirigentes y militantes, esta ley constituyó un freno parcial al avance especulativo de ciertas formas de "neolatifundismo" sobre los territorios indígenas. En algunos casos la causa se atribuye a los desacuerdos entre los gobiernos locales y ciertas organizaciones indígenas en algunas provincias (Neuquén y Formosa, por ejemplo) que habrían imposibilitado su aplicación con total efectividad (2014: 138). En otras situaciones la no aplicación de esta legislación encuentra explicación en las alianzas y connivencia entre gobiernos locales y grupos empresariales, donde el resguardo de intereses y beneficios económicos de los segundos se impone por sobre los reclamos de las organizaciones y pueblos indígenas, quienes tampoco encuentran amparo en los fueros legales locales y provinciales.

Trinchero y Valverde (2014), en un trabajo recientemente publicado por CLACSO, caracterizaron este proceso como "una combinación entre la creciente conformación de los pueblos indígenas como sujetos sociales, un reconocimiento jurídico que implica un avance (si bien con grandes dificultades en su concreción), políticas públicas que conllevan la participación y gestión (o cogestión) de algunos ámbitos gubernamentales y una estructura económica que, a contrapelo de lo anterior, recrea permanentemente procesos de desterritorialización de comunidades indígenas. Factores que, en definitiva, confluyen en una creciente presencia indígena, pero a la vez signan la paradójica realidad actual de estos pueblos, cuyos efectos se expresan en los agudos conflictos territoriales que se vienen registrando a lo largo del país" (2014: 2016).

Estos autores, al igual que los que han puesto en el centro de los análisis los aspectos económico-estructurales de este proceso, explican la compleja y contradictoria situación que caracteriza a la Argentina por la conjunción entre la genealogía histórica en la vinculación del Estado-nación con los pueblos originarios y los intereses que expresan las dinámicas de acumulación del capital extractivo regional (hidrocarburífero, agrario, turístico, etc.). Ello impone límites estructurales a la voluntad actual de transformación de las diversas políticas públicas específicas, así como a la concreción de múltiples derechos resultantes del reconocimiento hacia los pueblos originarios (Trinchero y Valverde, 2014: 2016). 
Esas contradicciones y los "límites estructurales", así como el desencuentro entre los gestos simbólicos de reconocimiento y la efectiva instrumentación de políticas que revirtieran la situación crítica de los pueblos originarios, encontraron en el gran acto por la conmemoración del Bicentenario de la Independencia Nacional un escenario y arena propicia para expresarse, un espacio simbólicamente habilitante para formular públicamente reclamos y denuncias.

Trinchero y Valverde (2014), recuperan como introducción a su artículo parte de la crónica de aquellos sucesos ofrecida por el diario Página/12, se enfatiza allí en que los grupos indígenas -representantes de diez distintas provincias- ingresaron a la Plaza de Mayo entonando la consigna "La tierra robada, será recuperada". La denominada "Marcha del Bicentenario" constituyó un hito, sostienen estos autores, no solo por lo que significó a nivel simbólico que numerosas columnas integradas por indígenas de todo el territorio nacional -recorriendo provincia a provincia en algunos casos-, viajaran hacia el corazón y capital del país para coparla con sus ropajes y consignas, sino también porque en paralelo a este acontecimiento sucederá un hecho inédito. Un conjunto de dirigentes indígenas fue recibido por la Presidenta de la Nación haciendo lugar a la entrega de un petitorio con sus principales reclamos. Otro factor que tornó paradigmático a este suceso es que representa un trascendental hecho político, pues divide y marca distintos posicionamientos entre las organizaciones indígenas, cuestiones que han sido analizadas por Briones (2015). Por un lado, numerosas organizaciones marcharon hacia la Plaza de Mayo para demostrar su apoyo a las políticas implementadas desde el Gobierno Nacional, encolumnándose con la multitud que acudió a festejar; por otro lado, al menos quince dirigentes de comunidades indígenas encabezaron una columna de manifestantes que, en representación de diversos Pueblos Originarios, exigieron ser atendidos por la Presidenta de la Nación, reafirmando en tal instancia que estaban allí para ratificar reclamos y por las deudas pendientes. En ocasión de la reunión con la mandataria entregaron un petitorio cuyos puntos centrales giraban en torno a la tierra y los recursos naturales, solicitando que efectivamente se les entregaran las tierras que les pertenecen y un compromiso de cancelar las concesiones hechas a las grandes corporaciones, para explotación minera e hidrocarburífera y para explotaciones forestales y desmontes en algunas regiones del país. Allí habrían resonado los planteos sobre "extranjerización de 
la tierra” y su expoliación, sobre la destrucción y expropiación de los recursos naturales y de los bienes comunes.

La multitudinaria presencia indígena en aquel gran suceso, su televisación y cobertura por los medios de comunicación implicó que, de cierto modo, las organizaciones indígenas se mostraran incluidas, integradas en los festejos conmemorativos, formando parte de esa Nación que se celebraba a sí misma. La contracara de esta imagen se expresó en el petitorio entregado a la Presidenta, donde se ratificaban las históricas deudas del Estado con los Pueblos originarios y se denunciaban las políticas depredatorias respecto a los recursos naturales y los beneficios de grandes corporaciones en ello. La cuestión que allí se denunciaba constituía entonces un tema de agenda que unos años antes se instaló públicamente y fue integrada al repertorio de reclamo de todos los colectivos sociales ambientalistas, indígenas y campesinos.

En el trabajo titulado "Audiencias y contextos: la historia de 'Benetton contra los mapuches", de Claudia Briones y Ana Ramos (2005), se analiza el conflicto entre la empresa Benetton y una familia mapuche de Chubut. Este, según sostienen, cobró una trascendencia, estatus y magnitud distinta a la que solían adquirir por entonces los casos jurídicos e injusticias que involucraban a indígenas en la provincia. Tal como postulan las autoras, el caso obtuvo rápidamente su formato de historia y su puesta en escena en distintos medios de difusión. Comenzó a conocerse a fines del ańo 2002, a partir de los comunicados de prensa de la "Organización de Comunidades Mapuche Tehuelche 11 de Octubre" (OCMT), que desde entonces acompañó a la familia mapuche que protagonizó el conflicto y enmarcó el caso en la lucha más amplia de un Pueblo, a la vez que este fue instalándose mediáticamente y alcanzó trascendencia nacional. Ello ilustra que en aquellos ańos no solo se había logrado situar el tema de la "extranjerización” como una preocupación y problema socialmente reconocido, sino también que en torno a este ya estaba operando una particular sensibilidad social. A partir de esta era posible juzgar la amenaza que constituía para los "legítimos" o "antiguos" propietarios de la tierra la concentración de las propiedades en mano de agentes anónimos y muy poderosos, de grandes empresas y corporaciones internacionales.

En relación al pueblo mapuche existen además estudios que enfocan estos procesos de "desapropiación" desde otro ángulo. En el trabajo "De- 
mandas territoriales del pueblo Mapuche en área de Parques Nacionales" Sebastián Valverde (2010), analiza el modo en que, durante la última década y a partir del ańo 2003, diversos grupos familiares mapuche activaron un recorrido de reafirmación identitaria y territorial dentro del área de Parques Nacionales, lo cual implica, en algunos casos, el retorno a territorios ancestrales de los que habían sido expulsados.

Se plantea que la reciente conformación de "comunidades" y su readscripción étnica mapuche está vinculada estrechamente con el diseño y planificación de diversas políticas estatales. Un hito significativo en ese sentido lo constituye la conformación del "Parque Nacional Nahuel Huapi”, en el ańo 1934 (en la región cordillerana de Norpatagonia), lo que apareja importantes consecuencias para "chilenos" e "indígenas", produciendo migración y expulsión de las áreas rurales ocupadas por estos pobladores. Sostiene el autor que el imaginario promovido por la elite conservadora de la década de 1930, consolidará la impronta de esta zona -y sus centros urbanos de referencia, San Carlos de Bariloche y Villa la Angostura- como un área pretendidamente "natural", "virgen", con reminiscencias "alpinas", construcción simbólica que habría cimentado el proceso de despojo. El cual, además, acentuaría la estigmatización y persecución de la cual ya habían sido objeto a partir de la denominada "Conquista del Desierto" que tuvo lugar a fines del Siglo XIX.

El autor formula como hipótesis que el proceso de "retorno" al territorio originario, en conjunción con un proceso de reactualización identitaria mapuche, se configura en el campo de posibilidades y límites dados por las transformaciones socioeconómicas y políticas que afectan a estos grupos familiares y las trayectorias histórico-sociales específicas de estos sujetos. Poseen una relevancia central las políticas de las jurisdicciones en que se han asentado históricamente estas poblaciones y en las cuales focalizan su reclamo en la actualidad. Esto incluye la manera en que han configurado a las poblaciones indígenas, el usufructo y acceso al territorio, y la forma en que estos posicionamientos han viabilizado u obstaculizado -en cada momentola etnicidad mapuche y las demandas territoriales. Se señala que Parques Nacionales, a contramarcha de la política restrictiva aplicada a lo largo del siglo XX, en la última década otorgó cierto reconocimiento a indígenas y criollos, mediante una forma de gestión que habilita la participación de las comunidades asentadas en la jurisdicción de Parques Nacionales. 
Sostiene Valverde (2010) que, una vez conformada esta institución, la política hacia los habitantes que quedaron dentro de su jurisdicción tuvo un carácter dual: muy laxa cuando se trataba de ceder territorios a vecinos prestigiosos, y sumamente estricta en el cumplimiento de las normativas vigentes si los aspirantes eran personas de escasos recursos -más aún si eran chilenos e indígenas-. "Mientras a los primeros se les otorgaron títulos de propiedad, a los segundos la Administración de Parques Nacionales les entregó Permisos Precarios de Ocupación y Pastaje [...] en muchos casos, ni siquiera los habitantes originarios lograron este estatus de ocupantes precarios, y la política fue la expulsión" (Valverde, 2010: 73). Añade el autor que, además, en concordancia con "la expropiación" hacia la población de escasos recursos, la institución fue clave en la impronta simbólica asignada a la región, concordante con el ideal estético y social que la clase dominante deseaba para el lugar: una suerte de "Suiza Argentina", favorecido esto por cierto parecido físico con los Alpes. De ello que en las áreas del Parque Nacional Nahuel Huapi la intensa política de expulsión y homogeneización de los pobladores rurales incidió en la estigmatización e invisibilización indígena, por ende, en la ausencia de reconocimiento de comunidades.

Sostiene Valverde que, en San Carlos de Bariloche, se efectuó un cambio sustancial al reconocer en la Carta Orgánica Municipal -modificada también en el año 2007-al Pueblo Mapuche como preexistente. Se evalúa que tal cambio confiere ciertas particularidades a las organizaciones originarias de Río Negro y Bariloche, las que se tornarían inteligibles solo a la luz de procesos históricos que han configurado determinadas relaciones interétnicas. También son estas particularidades las que explicarían el pedido de formalización de comunidades (que ya existían como tales, pero hoy solicitan su regularización), profundizándose así la heterogeneidad étnica mapuche ya presente (2010: 75-76).

El escenario fue ganando complejidad en los últimos años, según entiende el autor, dado que diversos grupos familiares que residen en las localidades de la zona -principalmente Bariloche, pero en menor medida Villa La Angostura y El Bolsón- vienen efectuando múltiples reafirmaciones identitarias y territoriales en los ámbitos originarios en diversas áreas del Parque Nacional Nahuel Huapi o de los ejidos municipales (que antes correspondían al área de reserva natural y luego fueron desafectadas al ser ampliados estos ejidos) [...] históricamente han hecho uso de dichos terri- 
torios -aunque no estuviera en muchos casos formalizado el usufructo de los mismos-, ya sea por diversas vinculaciones familiares, ocupaciones a través de trabajos estacionales y/u ocupaciones domésticas, es decir que siempre hubo presencia en los mismos (Valverde, 2010: 77).

Para el autor, el proceso de reafirmación identitaria y territorial es resultado de factores complejos y multicausales. En primer lugar, es en este ámbito urbano -al cual debieron migrar los indígenas fruto precisamente de un proceso de expulsión- donde se han producido las reactualizaciones identitarias mapuches, así como diferentes experiencias organizativas, en plena coincidencia con casos comparables en la Argentina y en el conjunto de América Latina. Este proceso responde también a las nuevas tendencias que precisamente explican la "Emergencia Indígena en América Latina” que caracteriza Bengoa (2009), antes mencionado. Plantea Valverde que, paradójicamente, la propia configuración de la "Suiza Argentina”, a partir de sus múltiples contradicciones ha creado el marco para la conformación de los indígenas como sujetos sociales y políticos, lo que les ha posibilitado reivindicar la posesión de sus territorios ancestrales (Valverde, 2010).

Desde otros estudios también se refuerza la línea de argumentación que ratifica la importancia de ejercitar una perspectiva procesual de largo alcance, considerando que las recientes derivaciones y dinámicas organizativas de los grupos indígenas se inscriben en un recorrido y trayectoria colectiva que atraviesa todo el siglo XX, se anuda a las configuraciones de poder locales, tiene que ver con las interrelaciones con diversos actores y encuentra en específicos hitos sus antecedentes y condiciones de posibilidad.

Tomando como caso paradigmático el de una comunidad kolla de Finca Santiago (Iruya, Salta), Marina Weinberg analiza el proceso de organización y lucha por "recuperar" su territorio y acceder a la propiedad de las tierras en las comunidades kollas de la puna salto-jujeña. Para Weinberg (2004), este caso puede ser tomado como paradigmático para abordar el proceso y recorrido histórico de demandas y reconocimientos de derechos entre pueblos indígenas y Estado en la Argentina. Entiende la autora que ello es así en la medida en que en el año 1994 -con la reforma de la Constitución y el reconocimiento de su pre-existencia- la comunidad obtuvo el título de propiedad comunitaria del territorio ancestralmente ocupado. Según entiende, esto se debe menos a una concesión de 
parte del Estado que a una larga lucha, al desarrollo de estrategias y a las distintas formas de organización política que fueron desarrollando a nivel comunitario y en relación a los estados nacional, provincial, municipal y con organizaciones no gubernamentales y organismos internacionales con injerencia en ese espacio local como el Banco Mundial.

La autora asume como punto de partida que la lucha por la tierra es un problema histórico en la Argentina y que, a pesar de los cambiantes escenarios a lo largo del siglo XX y principios del XXI, es un conflicto que aún no ha sido resuelto -esta evaluación, como antes se indicó, es compartida por los investigadores especializados en la temática-. Para sostener esta afirmación, Weinberg reconstruye distintos contextos y rastrea hitos significativos, que abarcan desde la instancia de "expropiación" del territorio a los pueblos indígenas mediante persecución y hostigamiento de esa zona entre fines del XIX y primeras décadas del XX (en la llamada Campaña del Chaco), la posterior apropiación por parte de las familias de elite salteña -donde se asienta el ingenio azucarero San Martín del Tabacal- y la consecuente explotación económica de ese territorio.

Se considera que la Campaña del Desierto fue el inicio de una etapa de persecución y sometimiento efectuado desde el Estado argentino hacia los pueblos indígenas que habitaban el territorio nacional, en las regiones de Pampa y Patagonia, esquema que luego se reprodujo en la ocupación de el Gran Chaco. "El principal objetivo de esos avances militares fue aumentar la cantidad de tierra disponible para la explotación capitalista en manos de unas pocas familias de la oligarquía nacional. Una vez logrado, las poblaciones originarias de esos territorios se vieron obligadas a transformarse en fuerza de trabajo de los nuevos propietarios de sus tierras ya que fueron desalojados de todos sus bienes, lo que constituía otro de los objetivos del plan de apropiación territorial (Weinberg, 2004: 46-47).

La investigadora entiende que, en la década de 1940, los reclamos de la población indígena tuvieron un nuevo espacio para ser escuchados, debido a las expectativas generadas entre la población de la Puna por las medidas que impulsó J.D. Perón desde la Secretaría de Trabajo. Ello fue de tal modo que "el 15 de mayo de 1946 partió desde Abra Pampa (Jujuy) una caravana bautizada como Malón de la Paz [...] conformada por representantes del pueblo kolla de Finca San Andres, Finca Santiago y otras comunidades de la Puna Jujeña [...] tenía como fin llegar a Buenos Aires a 
pedirle al presidente Perón que extendiese la justicia social a los indígenas" [...] "Si bien el acontecimiento no tuvo resultados positivos, es recordado como un hito fundamental que sentó precedentes en la lucha del pueblo kolla y luego fue recuperado como bandera en las demandas resurgidas hacia fines de la década del 80" (Weinberg, 2004: 51-53).

Este antecedente se suma a las condiciones que habilita la reforma de la Constitución Nacional de 1994. Para Weinberg, allí la comunidad kolla de Finca Santiago encontró un marco legal para viabilizar sus demandas y presentó una nueva propuesta de ley de expropiación de la Finca. En diciembre de 1999 les fue entregado el título de propiedad de las tierras a nombre de la comunidad indígena del Pueblo Kolla de Finca Santiago y desde entonces, con la tenencia legal, se empezó a recuperar y reconstruir su historia social y cultural, trabajo que se vio reforzado con la presencia del Consejo Kolla, que en 1997 sancionó su Estatuto General de funcionamiento" (2004: 55-56).

En el año 2000, esta comunidad se inscribe en un proceso de otras características, resultó seleccionada por el Banco Mundial para un proyecto de desarrollo orientado a la gestión de los recursos naturales. Tomando ese antecedente, Weinberg sostiene que "en la actualidad no se puede realizar ningún tipo de análisis sobre pueblos indígenas sin tener en cuenta su relación con el Estado, organizaciones no gubernamentales u organismos multilaterales de crédito". Desde esta perspectiva, se afirma que los pueblos indígenas deben ofrecer un discurso lo suficientemente homogéneo que le permita mostrar un elevado nivel de unidad hacia adentro independientemente de cómo sean las relaciones en la práctica. "Estas demandas provocan a la vez un proceso de reafirmación de su identidad que no está respaldado por una aceptación generalizada fuera de la comunidad. Se obliga a los pueblos indígenas a exacerbar su identidad a la vez que dicha identidad no encuentra eco positivo en el resto de la sociedad de la cual forman parte" (Weinberg, 2004: 61).

En la misma tónica de estos trabajos, pero poniendo el énfasis más que en el proceso de expropiación en las fatales consecuencias que este apareja, Álvarez Leguizamón (2011) analiza el vínculo entre la expansión del monocultivo de soja, al que llama sojización, y un caso de etnocidio. Además, liga este fenómeno a un conjunto de otras variables y dimensiones, proponiéndose poner de relieve la directa implicación entre las nuevas formas de ex- 
pansión del capitalismo y su lastre colonial, su carácter de colonialidad del poder. Se toma como caso la expansión de los cultivos de soja transgénica en Salta -localizada en la transición entre la yunga y el chaco seco- desde una perspectiva que vincula las formas actuales de producción de pobreza con el desarrollo de los agronegocios. La autora se focaliza en lo que considera "los síntomas dolorosos del proceso" y paradigmas de las formas de dominación neocoloniales del presente, el caso de las muertes por hambre de niños pertenecientes a los grupos indígenas - de la etnia wichí- que habitan en la zona de expansión de la frontera agropecuaria. Postula que la muerte por hambre en esa zona no sería novedosa, sino que se encuentra agudizada por los intensos procesos de expropiación de los medios de subsistencia necesarios para la reproducción de la vida, tales como el agua y el bosque.

El estudio se estructura en base a un conjunto de relaciones, principalmente entre nuevas formas de acumulación y producción de la pobreza: "los procesos de acumulación originaria, de transferencia de riquezas, de expropiación de medios de subsistencia dan cuenta de un "desarrollo particular del capitalismo local transnacionalizado” (2011: 19). Álvarez Leguizamón propone que este proceso cobra la forma de "un renovado modelo agroexportador globalizado", que habría sido promovido como las "mejores" políticas de "desarrollo nacional". Las que sin embargo concentran cada vez más la riqueza y producen pobreza y expropiación de medios de subsistencia". En ese sentido es que la soja se constituye en caso testigo, dado que la riqueza producida se concentra en los productores y la multinacional que monopoliza el rubro, siendo una típica forma de nuevo enclave productor de efectos depredadores (2011: 22).

Postula Álvarez Leguizamón que estas transformaciones "generan fuertes procesos de etnocidio" provocados por la ocupación del territorio que expulsa, desaloja o acorrala a las poblaciones que vivían de los recursos de monte. Retoma la clave de explicación también propuesta por los autores antes señalados, quienes vinculan este fenómeno con una suerte de acumulación originaria constante. "Se apropian medios de subsistencia y de reproducción material y cultural de la vida de grupos de población aborigen y campesina, con anuencia de los sectores de poder gubernamental y bajo discursos prácticos neocoloniales...” (Álvarez, 2011: 29).

Entre los distintos aportes que realiza este trabajo se puede resaltar la conexión entre los procesos que suceden a gran escala y su incidencia 
local, ofreciendo un panorama de las transformaciones neoliberales, sus territorializaciones y el desarrollo de los agronegocios en Salta. El análisis remite a aspectos específicos de las relaciones de dominación a escala local, a sus resabios coloniales, inscribiendo los procesos actuales en una larga temporalidad y de allí el anudamiento propuesto entre gubernamentalidad neoliberal y neocolonialismo.

En ese mismo sentido se orientan otros de los trabajos antes mencionados, con el propósito de poner de relieve el continuo despojo y expropiación que caracteriza la relación entre Estado y pueblos indígenas. En estos se enfatiza sobre los paralelismos entre el período de formación y despliegue del Estado capitalista (de fines del siglo XIX) y las transformaciones propias de su reestructuración neoliberal, agudizada desde la década de 1990 en adelante, a diferencia del anterior, que remite al matiz colonial de este. Si bien en ambos escenarios la cuestión territorial es la base de los ajustes y el lugar en donde las disputas se despliegan, hay diferencias sustantivas y condiciones históricas específicas que enmarcan una y otra. En ese sentido, sin duda el panorama presentado a través de los diversos estudios de caso reseńados hizo posible mostrar que los procesos de organización política y el reclamo por la tierra y el territorio también se remontan a la larga y profunda temporalidad. En ese sentido, aun cuando algunos autores enfaticen en que la novedad del escenario que se abre desde los años noventa en adelante es la irrupción de los grupos indígenas como sujetos colectivos y actores políticos organizados, otras perspectivas abogan por restituirles a esas formas organizativas sus historicidades propias, resaltando que si bien el modo en que se expresan las luchas del presente asumen caracteres y matices nuevos - habilitados por nuevos marcos jurídicos-, también en ellos es posible advertir la vigencia y rearticulación de experiencias y trayectorias tan antiguas como los despojos. Por lo tanto, inevitablemente, un estudio sobre los conflictos territoriales en el presente debe remontarse a la larga duración de los procesos y atender al complejo entramado de prácticas donde el avance del despojo y el reclamo de los despojados se implican mutuamente en el uso y aprovechamiento tanto de los nuevos repertorios y libretos - de inéditas herramientas y recursoscomo en la apelación a la memoria de antiguos saberes y tradiciones. 


\section{Conclusiones}

La convulsionada dinámica económica, político y social de mediados de los años noventa estalla en el año 2001 y prosigue con un período de renovados cambios políticos marcan el pulso de los temas, perspectivas y debates aquí presentados

Los investigadores que desarrollaron los estudios en el período 20002012, fueron interpelados por la crisis del año 2001. La crisis, al mismo tiempo que impulsó una agenda de temas relevantes, hizo nacer una nueva generación intelectual que simultáneamente mostró altos estándares de profesionalización combinado con un importante compromiso político en la tarea de analizar, comprender la configuración social de movimientos sociales durante el auge y la crisis del neoliberalismo.

El período analizado muestra una década intensa en conflictividad social, en el cual es posible reconocer un ciclo con dos etapas; la primera relacionada principalmente con los movimientos sociales organizados en torno a la crisis del mundo del trabajo. La segunda por la irrupción de los movimientos organizados en torno a la crítica al modelo de desarrollo extractivista y las luchas territoriales en contra del agronegocio, la megaminería y la ofensiva de las grandes empresas a los modos de vida de algunas comunidades. Un ciclo que va del protagonismo de los movimientos piqueteros a los movimientos socioambientales, en un espacio social que recorre casi toda la geografía del país.

La mayor parte de los investigadores sociales -sociólogos, politólogos, antropólogos, psicólogos, trabajadores sociales, economistas, filósofosconsolidaron un campo de estudio no exento de disputas y debates entre diversas perspectivas, pero que tuvo como marco común de análisis y crítica la teoría de los movimientos sociales en la perspectiva de la síntesis teórica norteamericana y europea. Aunque promediando la década y al calor de la emergencia de los gobiernos denominados progresistas, se comenzaron a utilizar teorías provenientes del pensamiento crítico latinoamericano y una gran cantidad asumió, del debate internacional, la categoría de "acumulación por desposesión" propuesta por Harvey.

Las investigaciones empíricas fueron la mayor parte de las veces estudios de casos, no obstante, los investigadores se preocuparon por establecer la conexión entre los procesos que suceden a gran escala y su inciden- 
cia local en la cual las tramas, trayectorias y experiencias organizativas fueron situadas, ofreciendo un panorama de las transformaciones neoliberales operadas en el territorio. Muchos de ellos inscribieron las luchas actuales en una larga temporalidad como es el caso de los estudios relacionados con los pueblos originarios.

En este sentido los casos resultan representativos y paradigmáticos, en la medida en que las formas de protesta y organización presentaron rasgos comunes con otros ámbitos y espacios, a la vez que informaron sobre la re-definición de los modos de interacción entre Estado y los movimientos y organizaciones sociales. Las demandas fueron respondidas con acciones estatales y su acción e intervención, en muchos casos en la forma de represión y criminalización, fueron gestando una trama que debió instalar en la agenda política los temas del trabajo, el desarrollo, la democracia participativa, las formas de intervención económica.

\section{Bibliografía}

Acosta, Alberto (2011), "Hacia la Declaración Universal de los Derechos de la Naturaleza. Reflexiones para la acción”, Alta Alegremia, en www.altaalegremia.com.ar.

Adelar, João Pizzeta (comp.) (2009), Método de trabajo y organización popular. Movimiento de los Trabajadores Rurales Sin Tierra (MST)-Brasil, El Colectivo, Buenos Aires.

Aiziczon, Fernando (2009), Zanón, una experiencia de lucha obrera, Herramienta-El Fracaso, Buenos Aires.

Altamira, Jorge (2002), El Argentinazo. El presente como historia, Rumbos, Buenos Aires.

Altschuler, Bárbara y Lecaro, Patricia (2002), "Políticas sociales y Desarrollo local. Dos Experiencias Diversas: Club del Trueque y Unión de Trabajadores Desocupados (UTD) de Mosconi”, Congreso de Políticas sociales, "Estrategias de Articulación de Políticas, Programas y Proyectos Sociales en Argentina", UNQ, Buenos Aires.

Álvarez Leguizamón, Sonia (2011), Neocolonialismo y hambre, los agronegocios de la soja transgénica, en CeBrelli, A. y ARANCiBiA, V. (coords.), Transformaciones y luchas sociales en Salta, CEPIHA, Salta. 
AndúJAR, Andrea (2005), "De la ruta no nos vamos: las mujeres piqueteras (1996-2001)", ponencia presentada en X Jornadas Interescuelas/Departamentos de Historia, Universidad Nacional de Rosario.

Auyero, Javier (2002), La Protesta. Retratos de la beligerancia popular en la Argentina democrática, Centro Cultural Rojas-UBA, Buenos Aires.

- (2004), Vidas Beligerantes. Dos mujeres argentinas, dos protestas y la búsqueda de reconocimiento, Editorial Universidad de Quilmes, Buenos Aires.

- (2007), La zona gris. Violencia colectiva y politica partidaria en la Argentina contemporánea, Siglo XXI, Buenos Aires.

AuYero, Javier y Swistun, Débora (2006), “Tiresias en Villa Inflamable. Hacia una cronografía de la dominación”, Sociohistórica, No 19-20, pp. 15-45.

Azuela, A. y N. Cosacov (2013), "Transformaciones urbanas y reivindicaciones ambientales. En torno a la productividad social del conflicto por la construcción de edificios en la Ciudad de Buenos Aires”, en revista EURE, vol. 39, no 118, pp. 149-172.

Bacchetta, V. (2013), "Geopolítica del fracking. Impactos y riesgos ambientales", Revista Nueva Sociedad, No 244, pp. 61-73.

Bañuelos, C., G. Mera y C. Rodríguez (2008), "Intervención-no intervención: ciudad y políticas públicas en el proceso de renovación del Área Sur de la Ciudad de Buenos Aires", en H. Herzer (org.), Con el corazón mirando al sur, Editorial Espacio, Buenos Aires.

Barbeito, Alberto y Lo Vuolo, Rubén Mario (1995), La modernización excluyente: transformación económica y Estado de bienestar en Argentina, UnicefCiepp-Losada, Buenos Aires.

Barone, Myrian Elena y Ruiz Diaz, Carolina (2011), "Pasaron veinticinco años y todo... sigue igual. Historia de la lucha y conflictos de grupos sociales relacionados con la Hidroeléctrica Yacyreta-Argentina/Paraguay", V Jornadas de Jóvenes Investigadores del IIGG, Buenos Aires.

BengoA, José (2000), La emergencia indígena en América Latina, Fondo de Cultura Económica, Santiago de Chile.

- (2009), “¿Una segunda etapa de la emergencia indígena en América Latina?”, Cuadernos de Antropología Social, No 29, Facultad de Filosofía y Letras-UBA, Buenos Aires, pp. 7-22. Recuperado en http://www.scielo.org.ar/pdf/cas/ n29/n29a01.pdf.

Bertinat, Pablo et al. (2014), 20 mitos y realidades del fracking, El Colectivo, Buenos Aires. 
Bilbao, Luis (2002), Chávez y la Revolución Bolivariana, Capital Intelectual, Buenos Aires.

- (2008), Venezuela en Revolución. Renacimiento del Socialismo, Capital Intelectual, Buenos Aires.

Bonasso, Miguel (2006), El palacio y la calle. Crónicas insurgentes y conspiradoras, Booket, Buenos Aires.

Bonifacio, José Luis (2009), Protesta y organización. Los trabajadores desocupados en la provincia de Neuquén, El Colectivo, Buenos Aires.

Boron, Atilio (2002), Imperio, Imperialismo. Una lectura critica de Michael Hardt y Antonio Negri, Clacso, Buenos Aires.

- (2012), América Latina en la geopolítica del imperialismo, Ediciones Luxemburg, Buenos Aires.

Briones, Claudia (2005), Cartografías argentinas. Políticas indigenistas y formaciones provinciales de la alteridad, Geaprona, Buenos Aires.

- (2015), "Políticas indigenistas en Argentina: entre la hegemonía neoliberal de los años noventa y la 'Nacional Popular' de la última década”, Antípoda. Revista de Antropología y Arqueología, No 21, enero-abril, Universidad de Los Andes, Bogotá, pp. 21-48.

Briones, Claudia y Ramos, Ana (2005), "Audiencias y contextos: la historia de Benetton contra los Mapuche”, E-misférica, Journal Electrónico del Hemispheric Institute of Performance and Politics. Issue 2(1), primavera. Disponible en http:www.hemisphericinstitute.org/jurnal/2_1/briones.html.

- (2010), "Replanteos teóricos sobre las acciones indígenas de reivindicación y protesta: aprendizajes desde las prácticas de reclamo y organización mapuche-tehuelche en Chubut", en Gordillo, Gastón y Hirsch, Silvia (comp.), Movilizaciones indígenas e identidades en disputa en la Argentina, La Crujía, Buenos Aires.

Buliubasich, Catalina y Rodríguez, Héctor E. (1997), "Reclamos de tierras indígenas en el Pilcomayo: el territorio como problema para las políticas públicas", ponencia presentada en el Simposio Ant37: Politicas publicas y territorios étnicos, del $49^{\circ}$ Congreso Internacional de Americanistas, Quito, 7 al 11 de julio.

CARman, M. (2011), Las trampas de la naturaleza. Medio ambiente y segregación en Buenos Aires, Fondo de Cultura Económica, Buenos Aires.

Carrasco, M. y Briones, Claudia (1996), La tierra que nos quitaron, IWGADinamarca y Asociación Lhaka Honhat, Salta. 
CASTEL, Robert (1997), Las metamorfosis de la cuestión social. Una crónica del salariado, Paidós, Buenos Aires.

Causa, Adriana y Ojam, Julieta (comps.) (2008), Mujeres piqueteras. Trayectorias, identidades, participación y redes, Baobab, Buenos Aires.

Ceceña, Esther Ana (2005), Bolivia. La guerra por el agua y por la vida, Madres de Plaza de Mayo, Buenos Aires.

Colectivo Situaciones y otros (2001), Contrapoder. Una introducción, Ediciones de mano en mano, Buenos Aires.

D’Hers, V. (2013), “Asentamientos sobre Basurales a cielo abierto. Explotación, Segregación y expulsión en el manejo de los residuos", en revista DELOS, Desarrollo Local Sostenible, vol. 6, No 16.

Delamata, G. (2009), “¿La ciudadanía poblana? El movimiento asambleario de Gualeguaychú y la construcción y el reclamo de un derecho colectivo”, en Movilizaciones sociales: ¿nuevas ciudadanias? Reclamos, derechos, Estado en Argentina, Bolivia y Brasil, Biblos, Buenos Aires.

Di Virgilio, M.M. (2011), "Producción de la pobreza y políticas públicas: encuentros y desencuentros en urbanizaciones populares del Área Metropolitana de Buenos Aires", en Arzate Salgado, Gutiérrez y Huamán (coords.), Reproducción de la pobreza en América Latina Relaciones sociales, poder y estructuras económicas, Buenos Aires, CLACSO-CROP, Buenos Aires.

Di Risio, D. y Cabrera, F. (2014), Fracturando límites. Argentina: el desembarco del fracking en Latinoamérica, Amigos de la Tierra (Francia)/Observatorio Petrolero Sur, Buenos Aires.

Di Risio, Diego; Gavaldá, Marc; Pérez Roig, Diego y Scandizzo, Hernán (2012), Zonas de sacrificio. Impactos de la industria hidrocarburifera en Salta y la Norpatagonia, América Libre, Observatorio Petrolero Sur, Buenos Aires.

Díaz Muñoz, Marco (2005), Orden, represión y muerte: Diario de la criminalización de la protesta social, en Salta, 1995-2005, Tierra del Sur y Colectivo La Rabia, Córdoba.

Dinerstein, Ana Cecilia, Contartese, Daniel y Deledicque, Melina (2008), "Notas de investigación sobre la innovación organizacional en entidades de trabajadores desocupados en la Argentina”, en Revista de Ciencias Sociales. Realidad Económica, publicado el 14 de mayo de 2008, Buenos Aires.

EchagüE, Hernán López (2002), La política está en otra parte. Viaje al interior de los nuevos movimientos sociales, Norma, Buenos Aires. 
Escolar, Diego (2007), Dones étnicos de la Nación. Identidades huarpe y modos de producción de soberania en Argentina, Prometeo, Buenos Aires.

Espinosa, Cecilia (2010), "Experiencias militantes, experiencias de género. $\mathrm{Mu}-$ jeres y espacio de mujeres en una organización "piquetera”, Seminario Internacional Fazendo Generos, No 9.

Fernández, Ana María et al. (2008), Política y Subjetividad. Asambleas barriales y fábricas recuperadas, Biblos, Buenos Aires.

Fradkin, Raúl O. (2002), Cosecharás tu siembra. Notas sobre la rebelión popular argentina de diciembre de 2001, Prometeo Libros, Buenos Aires.

Galaffasi, Guido (2009), “Estado, capital y acumulación por desposesión. Los espacios rurales patagónicos y su renovado perfil extractivo de recursos naturales", en Páginas, Vol 1, No 2, Escuela de Historia, Facultad de Humanidades y Artes-UNR, Rosario.

Giarraca, Norma (2007), "La tragedia del desarrollo: disputas por los recursos naturales en la Argentina”, en Sociedad, vol. 3, Buenos Aires.

Giarracca, Norma (comp.), con colaboración de Miguel Teubal et al. (2011) Bicentenarios (otros), transiciones y resistencias, Una Ventana, Buenos Aires.

Giarracca, Norma y Teubal, Miguel (2001), "El movimiento de mujeres agrarias en lucha”, en Giarraca, N. et al., La protesta social en la Argentina. Transformaciones económicas y crisis social en el interior del país, Alianza, Buenos Aires.

- (2008), "Del desarrollo agroindustrial a la expansión del agronegocio: el caso argentino", en Mançano Fernandes, Bernardo (org.), Campesinato e agronegócio na América Latina: a questão agrária atual, San Pablo, CLACSO-Expressão Popular.

Goméz, Marcelo (2014), El regreso de las clases. Clase, acción colectiva y movimientos sociales, Biblos. Buenos Aires.

GonzÁlez Bombal, Inés (2002), "Sociabilidad en clases media en descenso: experiencia en el trueque”, en A.A.V.V., Sociedad y Sociabilidad en la Argentina de los noventa, UNGS-Biblos, Buenos Aires.

Gordillo, Gastón y Leguizamón, J.M. (2002), El río y la frontera. Movilizaciones aborigenes, obras públicas y Mercosur en el Pilcomayo, Biblos, Buenos Aires.

Gordillo, Gastón y Hirsch, Silvia (2010), Movilizaciones indígenas e identidades en disputa en la Argentina, La Crujía-Flacso, Buenos Aires.

Gorosito Kramer, Ana María (2008), “Convenios y leyes: La retórica políticamente correcta del Estado”, Cuadernos de Antropología Social, No 28. 
Gras, C. y Hernández, V. (coord.) (2009), La Argentina rural. De la agricultura familiar a los agronegocios, Biblos, Buenos Aires.

Gudynas, Eduardo (2009), "Diez tesis urgentes sobre el nuevo extractivismo", en A.A.V.V., Extractivismo, politica y sociedad, CAAP (Centro Andino de Acción Popular) y CLAES (Centro Latino Americano de Ecología Social), Quito.

- (2011), “Tensiones, contradicciones y oportunidades de la dimensión ambiental del Vivir Bien", en Farah, Ivonne y Vasapollo, Luciano (coords.), Vivir Bien: ¿Paradigma no Capitalista?, CIDES-UMSA/Sapienza Universitá di Roma/Oxfam/Plural, La Paz.

Hardt, Michael y Negri, Antonio (2002), Imperio, Paidós, Buenos Aires.

Harvey, David (2003), El nuevo imperialismo, Akal, Madrid.

Hernández, Valeria y Svampa, Maristella (comp.) (2008), Gérard Althabe, entre dos mundos. Reflexividad, conocimiento y compromiso, Prometeo, Buenos Aires.

Hirsch, Silvia y Ciccone, Florencia (2010), "Representaciones culturales y lingüísticas en el resurgimiento identitario de los tapietes”, en Gastón GordiLlo y Silvia Hirsch (comps.), Movilizaciones indígenas e identidad en disputa en la Argentina, La Crujía-Flacso, pp. 123-145.

Holloway, John, Matamoros, Fernando y Tischler, Sergio (2008), Zapatismo. Reflexión teórica y subjetividades emergentes, Herramienta, Buenos Aires.

Holloway, John. (2002), Cambiar el mundo sin tomar el poder. El significado de la revolución hoy, Colección Herramienta-Universidad Autónoma de Puebla, Buenos Aires.

IÑigo Carrera, Nicolás y Cotarelo, María Celia (2003), "Argentina, diciembre de 2001: hito en el proceso de luchas populares", Movimientos sociales y confictos en América Latina.

Jelin, Elizabeth (comp.) (1985), Los nuevos movimientos sociales. Mujeres. Rock nacional. Derechoshumanos. Obreros. Barrios, Centro Editor de América Latina, Buenos Aires.

KARASIK, Gabriela (2010), "Subalternidad y ancestralidad colla: transformaciones emblemáticas y nuevas articulaciones de lo indígena en Jujuy”, en GordLlo, Gastón y Hirsch, Silvia (comps.), Movilizaciones indígenas e indentidades en disputa en la Argentina, La Crujía-Flacso, Buenos Aires, pp. 259-283.

Kohan, Aníbal (2002), ;A las calles! Una historia de los movimientos piqueteros y caceroleros de los '90 al 2002, Colihue, Buenos Aires. 
Korol, Claudia (2010), Resistencias populares a la recolonización del continente (Primera y segunda parte), América Libre, Buenos Aires.

LAZZARI, Axel (2007), "Identidad y fantasma: situando las nuevas prácticas de libertad del movimiento indígena en La Pampa”, Quinto Sol, No 11, enerodiciembre.

LEFF, Enrique (2007), Saber ambiental: sustentabilidad, racionalidad, complejidad, poder, México, Siglo XXI.

Lenton, Diana y Lorenzetti, Mariana (2005), "Neoindigenismo de necesidad y urgencia: la inclusión de los Pueblos Indígenas en la agenda del Estado neoasistencialista”, en Briones, Claudia (ed.), Cartografias argentinas. Politicas indigenistas y formaciones provinciales de alteridad, Antropofagia, Buenos Aires.

Liaudat, María Dolores, Liaudat, Santiago y Pis Diez, Nayla (2012), En las aulas y en las calles. Antecedentes, continuidades y rupturas de una década de movimiento estudiantil universitario argentino (2002-2011), Herramienta, Buenos Aires.

López Echagüe, Hernán (2002), La política está en otra parte. Viaje al interior de los nuevos movimientos sociales, Editorial Norma, Buenos Aires.

Luzzani, Telma (2008), Venezuela y la Revolución. Escenarios de la Era Bolivariana, Capital Intelectual, Buenos Aires.

Machado Aráoz, Horacio (2010), Minería transnacional y neocolonialismo. Cuerpos y territorios en las disputas coloniales de nuestro tiempo. Resistencias Populares a la Recolonización del Continente. Primera Parte, Buenos Aires, pp. 289-327.

- (2011), “'Agua Rica'. Conflicto colonial. Guerra de religiones. En Bicentenarios (otros), transiciones y resistencias", en Norma Giarraca (comp.) con colaboración de Miguel Teubal et al., Buenos Aires, Una Ventana, 1a ed.

Magnani, Esteban (2003), El cambio silencioso. Empresas y fábricas recuperadas por los trabajadores en la Argentina, Prometeo Libros, Buenos Aires.

MançAno Fernandes, Bernardo (2000), Brava Gente. Entrevista a João Pedro Stedile, Madres de Plaza de Mayo, Buenos Aires.

Massuh, Gabriela (ed.) (2012), Renunciar al bien común. Extrativismo y (pos) desarrollo en América Latina, Mardulce, Buenos Aires.

Mazzeo, Miguel (2004), Piqueteros. Notas para una tipología, Manuel Suárez Editor, Buenos Aires.

McAdam, Dough, McCarthy, John y Zald, Mayer (eds.) (1999), Movimientos Sociales: perspectivas comparadas, Istmo, Madrid. 
Melucci, Alberto (1994), “¿Qué hay de nuevo en los 'nuevos movimientos sociales'?”, en Lasaña, C. y Guefield, J. (ed.), Los nuevos movimientos sociales. De la ideología a la identidad, Centro de Investigaciones Sociológicas (CIS), Madrid.

Merklen, Denis (2005), Pobres ciudadanos. Las clases populares en la era democrática argentina, 1983-2003, Gorla, Buenos Aires.

Merlinsky, M.G. (2008), “La gramática de la acción colectiva ambiental en Argentina. Reflexiones en torno al movimiento ciudadano ambiental de Gualeguaychú y su inscripción en el espacio público", Temas y Debates, No 15 .

- (2013), Política y justicia ambiental en la metrópolis de Buenos Aires. El conflicto del Riachuelo, Fondo de Cultura Económica, Buenos Aires.

Mirza, Cristián Adel (2006), Movimientos sociales y sistemas políticos en América Latina. La construcción de nuevas democracias, Clacso Libros, Buenos Aires.

Movimiento de Trabajadores Desocupados Aníbal Verón (2003), Darío y Maxi. Dignidad Piquetera. El gobierno de Dubalde y la planificación criminal de la masacre del 26 de junio en Avellaneda, Ediciones 26 de Junio, Buenos Aires.

MTD de Solano y Colectivo Situaciones (2002), Hipótesis 891. Más Allá de los piquetes, Ediciones de mano en mano, Buenos Aires.

OuviÑa, Hernán (2007), Zapatismo para principiantes, Era naciente, Buenos Aires.

Oviedo, Luis (2001), Una historia del movimiento piquetero. De las primeras coordinadoras a las asambleas nacionales, Rumbo, Buenos Aires.

Palermo, Vicente y Reboratti, Carlos (2007), Del otro lado del río: ambientalismo y politica entre uruguayos y argentinos, Edhasa, Buenos Aires.

Pérez Roig, D. (2012), "Los hidrocarburos no convencionales en el escenario energético argentino", Theomai, № 25.

Petruccelli, Ariel (2005), Docentes y Piqueteros. De la Huelga de Aten a la pueblada de Cutral Co, Ediciones El Cielo por Asalto-El Fracaso, Buenos Aires.

Picchetti, Valentina y Xiques, Mario (2003) “Ocupación de fábricas y construcción políticas", ponencia presentada en ASET "Los Trabajadores y el trabajo en la crisis", 60 Congreso Nacional de Estudios del Trabajo, Buenos Aires.

Pintos, Patricia y Narodowsky, Patricio (2012), La privatopía sacrílega, Efectos del urbanismo privado en humedales de la cuenca baja del Río Luján, Buenos Aires, Imago Mundi.

Pizzeta, Adelar João (comp.) (2009), Método de trabajo y organización popular 
Movimiento de los Trabajadores Rurales Sin Tierra (MST), Editorial El Colectivo, Buenos Aires.

Radovich, Juan Carlos (2014), "Política indígena y movimientos etno-políticos en la Argentina contemporánea. Una aproximación desde la Antropología Social", Revista Antropologías del Sur, año I, N 1 .

Ramonet, Ignacio (2001), Marcos la dignidad rebelde, Capital Intelectual, Buenos Aires.

Rebón, Julián (2004) Desobedeciendo al desempleo. La experiencia de las empresas recuperadas, Ediciones Picaso-La Rosa Blindada, Buenos Aires.

Rebón, Julián y SaAvedra, Ignacio (2006), Empresas Recuperadas La autogestión de los trabajadores, Capital Intelectual, Buenos Aires.

Reboratti, C. (2010), "Un mar de soja: la nueva agricultura en Argentina y sus consecuencias", Revista de Geografía Norte Grande, (45), pp. 63-76.

Rodríguez Gavarito, Cesár, Barrett, Patrick y Chávez, Daniel (2005), La nueva izquierda en América Latina, Norma, Buenos Aires.

Ruggeri, Andrés, Polti, Natalia y Antivero, Javier (2010), "Las empresas recuperadas en la Argentina. 2010: informe del tercer relevamiento de empresas recuperadas por los trabajadores", Programa Facultad Abierta, Facultad de Filosofía y Letras Universidad de Buenos.

Rulli, Jorge y Boy, Adolfo (2007), "Monocultivos y Monocultura: La pérdida de soberanía alimentaria. Repúblicas Unidas de la Soja. Realidades sobre la producción de soja en América del Sur”, Grupo de Reflexión Rural.

Sabio Collado, María Victoria (2013), "Revisibilización indígena, memoria e identidad en una comunidad urbana. Las marcas de los 'ancestros' diaguitas”, Claroscuro Revista del Centro de Estudios sobre Diversidad Cultural, No 12.

Schiavoni, Gabriela (2005), "El experto y el pueblo: la organización del desarrollo rural en misiones (argentina)", Desarrollo económico, pp. 435-453.

Schuldt, Jürgen y Acosta, Alberto (2009), "Petróleo, rentismo y subdesarrollo. ¿Una maldición sin solución?”, en A.A.V.V., Extractivismo, política y sociedad, CAAP/CLAES, Quito.

Schuster, Federico (2005), "Las protestas sociales y el estudio de la acción colectiva”, en Schuster, Federico, Naishtat, Francisco, Nardacchione, Gabriel y Pereyra, Sebastián (comps.), Tomar la palabra. Estudios sobre protesta social y acción colectiva en la Argentina contemporánea, Prometeo, Buenos Aires.

Schuster, Federico; Naishtat, Francisco; Nardacchione, Gabriel; Pereyra, Sebastián (comps.) (2005), Tomar la palabra. Estudios sobre protesta social y 
acción colectiva en la Argentina contemporánea, Prometeo Libros. Buenos Aires.

Schuster, Federico y Pereyra, Sebastián (2001), “Transformaciones de la protesta social en Argentina: balance y perspectivas de una forma de acción política”, en Giarraca, Norma (comp.), Protesta social en Argentina. Transformaciones económicas y crisis social en el interior del pais, Alianza, Buenos Aires.

Seonne, José (comp.) (2003), Movimientos Sociales y Conflicto en América Latina, Clacso, Buenos Aires.

SeoAne, José y TAddei, Emilio (2010), "Cuando las aguas bajan turbias: la lucha contra las pasteras en el Río de la Plata y el movimiento social ambientalista en el Uruguay", en Seoane, Taddei y Algranati, Recolonización, bienes comunes de la naturaleza y alternativas desde los pueblos, Río de Janeiro/Buenos Aires: Diálogo de los Pueblos y Geal.

Seoane, José, Taddei, Emilio y Algranati, Clara (2009), Recolonización, bienes comunes de la naturaleza y alternativas desde los pueblos, Diálogo de los Pueblos y Grupo de Estudios sobre América Latina y el Caribe (Geal).

Sigal, Silvia (2010), "Prefacio", en Merklen, Denis, Pobres ciudadanos. Las clases populares en la era democrática argentina, 1983-2003, Editorial Gorla, Buenos Aires, 2a edición.

Slutzky, Daniel, Rofman, Alejandro y Di Loreto, María (2003), "Experiencias autogestionarias en un marco de crisis económico-social inédita: las empresas recuperadas", ponencia presentada en el VI Congreso Nacional de Estudios del Trabajo, ASET, del 13 al 16 de agosto, Buenos Aires.

Stefanoni, Pablo y Do Alto, Hervé (2006), La Revolución de Evo Morales. De la coca al palacio, Capital Intelectual, Buenos Aires.

Svampa, Maristella (2005), La sociedad excluyente. Argentina bajo el signo del neoliberalismo, Taurus, Buenos Aires.

- (2008a), Cambio de época. Movimientos Sociales y poder politico, Siglo XXI, Buenos Aires.

— (2008b), "Notas provisorias sobre la sociología, el saber académico y el compromiso intelectual", en Hernández, Valeria y SvAmpa, Maristella (comp.), Gérard Althabe, entre dos mundos. Reflexividad, conocimiento y compromiso, Prometeo, Buenos Aires.

- (2012), "Consenso de los commodities, giro ecoterritorial y pensamiento crítico en América Latina”, Revista OSAL, año XIII, Nº 32. 
- (2013), “Consenso de los Commodities' y lenguajes de valoración en América Latina”, Nueva Sociedad, No 244, marzo-abril de 2013.

Svampa, Maristella (ed.) (2000), Desde Abajo. Política. La transformación de las identidades sociales, Buenos Aires, Biblos-UNGS.

Svampa, Maristella y Antonelli, Mirta (eds.) (2009), Minería transnacional, narrativas del desarrollo y Resistencias sociales, Biblos, Buenos Aires.

Svampa, Maristella y Machado Aráoz, Horacio et al. (Colectivo Voces de Alerta) (2011), 15 mitos y realidades sobre la minería transnacional en Argentina, El Colectivo-Ediciones Herramienta, Buenos Aires.

Svampa, Maristella y Pereyra, Sebastián (2009 [2003]), Entre la ruta y el barrio. La experiencia de las organizaciones piqueteras, Biblos, 2a. edición actualizada, Buenos Aires.

Svampa, Maristella, Sola Álvarez, M. y Bottaro, L. (2009), "Los movimientos contra la minería a cielo abierto: escenarios y conflictos", en Svampa, M. y Antonelli, M. (comps.), Minería transnacional, narrativas del desarrollo y resistencias sociales, Biblos, Buenos Aires.

Svampa, Maristella y Stefanoni, Pablo (coords.) (2007), Bolivia. Memoria, insurgencias y movimientos sociales, El colectivo, en coedición con Osal-Clacso, Buenos Aires.

Svampa, Maristella, Stefanoni, Pablo y Fornillo, Bruno (2010), Debatir Bolivia. Perspectivas de un proyecto de descolonización, Taurus, Buenos Aires.

Svampa, Maristella y Viale, Enrique (2014), Maldesarrollo. La Argentina del extractivismo y el despojo, Katz, Buenos Aires.

Schweitzer Alejandro Fabián (2014), "Patagonia, naturaleza y territorios. Geograficando”. Disponible en: <http://www.geograficando.fahce.unlp.edu.ar/ article/view/Geov10n02a11>.

TAmagno, Liliana (2014), "Políticas indígenas hoy. Un nuevo 'parto de la antropología'. Etnicidad y clase”, en Trinchero, Hugo, Campos Muñoz, Luis y VAlverde, Sebastián (coords,), Pueblos indígenas, Estados nacionales y fronteras Tensiones y paradojas de los procesos de transición contemporáneos en América Latina, tomo II, Buenos Aires, FFyL-UBA, Clacso y Universidad Academia. TAmagno, Liliana (coord.) (2009), Pueblos indígenas. Interculturalidad, colonialidad, politica, Biblos, Buenos Aires.

TARrow, Sidney (2004), El poder en movimiento. Los movimientos sociales, la acción colectiva y la política, Alianza Editorial, Madrid.

Teubal, M. (2001), "Globalización y nueva ruralidad en América Latina”, en 
Giarracca, N. (coord.), Una nueva ruralidad en América Latina, pp. 45-65. CLACSO, Buenos Aires.

Thwaites Rey, Mabel (2004), La Autonomía como búsqueda, El Estado como contradicción, Prometeo, Buenos Aires.

Tilly, Charles (1986), The Contentious French, Harvard University Press, Cambridge.

Toledo, Llancaqueo (2005), "Políticas indígenas y derechos territoriales en América Latina: 1990-2004. ¿Las fronteras indígenas de la globalización?”, en Dávalos, Pablo (comp.), Pueblos indígenas, estado y democracia, CLACSO, Buenos Aires, también: http://bibliotecavirtual.clacso.org.ar/ar/libros/davalos/CapToledo.pdf Editorial/Editor.

Touraine, Alain (1987), El regreso del actor, Eudeba, Buenos Aires.

Trinchero, Hugo y Valverde, Sebastián (2014), “De la 'guerra con el indio' a los pueblos originarios como sujetos sociales y políticos: del Centenario al Bicentenario argentino", en Trinchero, Hugo, Campos Muñoz, Luis y VAlverde, Sebastián (coords.), Pueblos indígenas, Estados nacionales y fronteras. Tensiones y paradojas de los procesos de transición contemporáneos en América Latina, CLACSO, FFyL-UBA, Buenos Aires.

Valverde, Sebastián (2010), "Demandas territoriales del pueblo mapuche en área de Parques Nacionales", Avá. Revista de Antropología, № 17.

VÁzquez, Melina (2009), "La política desde abajo: narrativas militantes de jóvenes desocupados y desocupadas en Argentina”, Revista Latinoamericana de Ciencias Sociales, vol. 7, No 1.

Vinelli, Natalia y Rodríguez Esperón, Carlos (comps.) (2004), Contrainformacion Medios Alternativos para la Acción Política, Peña Lillo/Continente, Buenos Aires.

WAGNER, Lucrecia (2012), "Uspallata: ecos sociales de la megaminería en un valle andino”, CLAROSCURO, Revista del Centro de Estudios sobre Diversidad Cultural (CEDCU), Rosario, pp. 191-215.

Weinberg, Marina (2004), "Identidades y organización política en la comunidad kolla de Finca Santiago. Iruya-Salta”, Revista Estudios sociales del NOA, No 7.

Zibechi, Raúl (2003), Genealogía de la revuelta. Argentina la sociedad en movimiento, Letra Libre, La Plata.

- (2011), "Tensiones entre extractivismo y redistribución en los procesos de cambio", Aldeah, <www.aldeah.org/es/raul-zibechitensiones-entre-extractivismo-yredistribucion-en-los-procesos-de-cambio-de-america-lat>, 20/1/2011. 